\title{
38. NEOGENE TURBIDITE SEQUENCE ON THE MADEIRA ABYSSAL PLAIN: BASIN FILLING AND DIAGENESIS IN THE DEEP OCEAN ${ }^{1}$
}

\author{
P.P.E. Weaver, ${ }^{2}$ I. Jarvis,${ }^{3}$ S.M. Lebreiro, ${ }^{2}$ B. Alibés ${ }^{4}$ J. Baraza,${ }^{4}$ R. Howe,${ }^{5}$ and R.G. Rothwell ${ }^{2}$
}

\begin{abstract}
The Madeira Abyssal Plain (MAP) has been formed by the accumulation of turbidite sediments from three principal sources: the northwest African continental margin, the Canary Islands and the Hyères/Cruiser/Great Meteor seamount chain. Turbidites derived from each of these sources have distinct chemical signatures enabling the development of a high-resolution chemostratigraphy, in addition to the conventional bio- and lithostratigraphies. Individual beds can be up to a few meters thick, and many are traceable across the whole plain. The first turbidites rapidly infilled the fracture zone valleys through the middle Miocene. By $16 \mathrm{Ma}$, the fracture zones were nearly filled, and flows began to spread across wider areas to form the plain. Between 16 and $13 \mathrm{Ma}$, individual flows became much larger, so that after this time, correlation of individual beds is possible between Sites 950, 951, and 952, which are spaced 50-60 km apart. Accumulation rates of the three principal groups of turbidites increased between 7 and $6.5 \mathrm{Ma}$, and remain high to the present day. One subgroup, termed "gray nonvolcanic turbidites," show a pulsed input to the plain, which may be related to the early growth phases of individual Canary Islands. The pelagic interbeds are composed of clay through the Eocene to middle Miocene, but at $8 \mathrm{Ma}$, they show a small increase in carbonate content. This increases again at $\sim 5 \mathrm{Ma}$, and at $3.5 \mathrm{Ma}$, the carbonate began to oscillate between clays and oozes, reflecting the Pliocene-Quaternary climatic fluctuations.

Diagenesis of MAP Miocene-Holocene sediments is dominated by oxic processes that occurred when organic-rich turbidites were first emplaced on the plain. Diffusion of seawater oxygen into the upper few decimeters of turbidite tops and over time periods of a few thousand years caused the near-complete destruction of labile organic matter in the sediment, and promoted the early diagenetic migration of trace metals around a sharply defined redox interface. Pore-water data demonstrate that subsequent burial to depths of > 350 meters below seafloor, and for time periods in excess of $10 \mathrm{~m} . \mathrm{y}$. , has led to the progressive development of post-oxic, sulfate-reducing, and methanogenic environments, but these have had remarkably little effect on bulk sediment composition, trace-metal distributions, or organic-matter geochemistry. Oxygen availability appears to be an overriding control on diagenetic processes and rates during early burial in these pelagic environments.
\end{abstract}

\section{INTRODUCTION}

Drilling of the complete turbidite sequence in the Madeira Abyssal Plain (MAP) represents the culmination of 24 years of research in this area. The MAP was selected in the late 1970s as a study area for the feasibility of radioactive waste disposal in the oceans, and subsequently, its sediment cover was intensively investigated to a depth of $34 \mathrm{~m}(750 \mathrm{k.y}$.$) . A full background to our knowledge of the MAP sed-$ iments can be found in papers by Weaver and Kuijpers (1983), Weaver and Rothwell (1987), Weaver et al. (1986), Weaver at al. (1989), and Rothwell et al. (1992). The geochemical characterization of the sediments is given in Colley and Thomson (1985), De Lange et al. (1987, 1989), Thomson et al. (1987), Jarvis and Higgs (1987), and Pearce and Jarvis (1992a, 1992b, 1995). In brief, the salient points from this research into the upper Quaternary sedimentary sequence are as follows:

1. Large turbidites are deposited on the abyssal plain at infrequent intervals. Most flows cover the whole plain and can have volumes in excess of $200 \mathrm{~km}^{3}$. Only rarely do two or more

${ }^{1}$ Weaver, P.P.E., Schmincke, H.-U., Firth, J.V., and Duffield, W. (Eds.), 1998. Proc. ODP Sci. Results, 157: College Station, TX (Ocean Drilling Program).

${ }^{2}$ Southampton Oceanography Centre, Empress Dock, Southampton, S014 3ZH, United Kingdom.ppew@soc.soton.ac.uk

${ }^{3}$ School of Geological Sciences, Kingston University, Penrhyn Road, Kingston upon Thames, Surrey KT1 2EE, United Kingdom.

${ }^{4}$ UA Geociencias Marinas CSIC-UB; GRC Geociències Marines, Dep. Geologia Dinàmica, Geofísica i P., Universitat de Barcelona, Campus de Pedralbes, 08071 Barcelona, Spain.

${ }^{5}$ Department of Geology and Geophysics, The University of Western Australia, Nedlands, WA 6907, Australia. flows lie on top of one another without a pelagic layer between.

2. Turbidites are dominantly fine-grained muds, with sandy bases located near their entry point onto the abyssal plain.

3. Through the last 750 k.y., most flows were deposited at times of falling and rising sea levels. Only a small number were deposited during low- and highstands of sea level.

4. The turbidity currents cause insignificant erosion as they cross the abyssal plain, so the pelagic sequences between turbidites are intact.

5. Three primary sources have been identified: the northwest African margin, volcanic islands of the Canaries, and the Hyères/ Cruiser/Great Meteor seamount chain to the west of the abyssal plain.

Although defined by a range of geochemical and other criteria, the three main turbidite groups may be distinguished using only $\mathrm{Ca}, \mathrm{Ti}$, and Al data (De Lange et al., 1987, 1989; Pearce, 1991; Pearce and Jarvis, 1992a, 1995; Jarvis et al., Chap. 31, this volume). Organicrich turbidite muds (i.e., excluding basal sands and silts) have the lowest $\mathrm{Ca}$ contents (presented here as $\mathrm{CaCO}_{3}$, because the bulk of the $\mathrm{Ca}$ present occurs in the carbonate fraction), typically $45 \%-55 \%$ $\mathrm{CaCO}_{3}$. These muds also have low but constant Ti:Al ratios of $\sim 0.05$. Volcanic turbidite muds have intermediate carbonate contents, generally $55 \%-65 \%$, and high but variable Ti:Al ratios of 0.08 to 0.2 . Calcareous turbidite muds are defined as having $>75 \% \mathrm{CaCO}_{3}$, but also exhibit marginally higher $\mathrm{Ti}: \mathrm{Al}$ ratios than the organic-rich group, with values $\sim 0.06$.

The MAP investigations ended in the late 1980s, and since then, the data obtained have been developed into a model for basin development and filling by further research on the continental slope and rise of the northwest African margin and Canary Islands (Weaver et

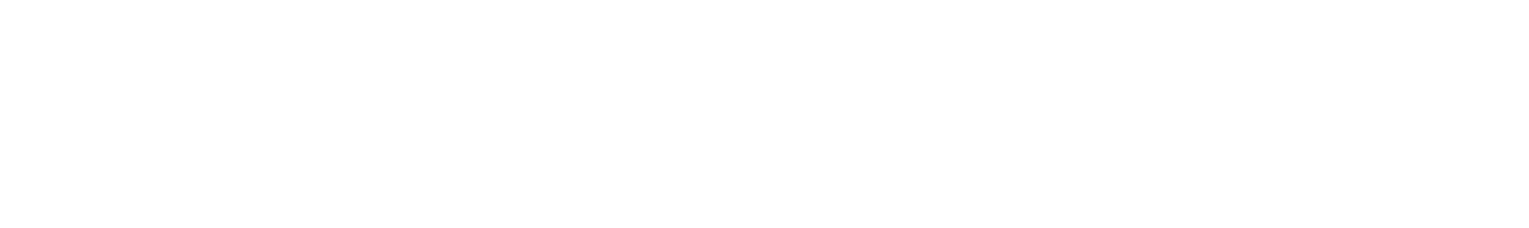


al., 1992, 1995). This research has concentrated on the upper sediment column, which can be imaged by side-scan sonar and cored by conventional piston and gravity corers. Individual mass-wasting events have been identified, and depositional units, such as debris avalanches, debris flows, and turbidites, correlated from their source on the Canary island slopes or African margin to the distal abyssal plain (Masson et al., 1992; Masson, 1996). Our research suggests that all major mass-wasting events produce turbidity currents large enough to cross the continental slope and rise, eventually depositing on the abyssal plain. The work to date has essentially provided a two-dimensional plan view of a small number of events. Some idea of the timing and frequency of events was provided by the longer piston cores on the abyssal plain (Weaver et al., 1992). The objective of Leg 157 was to attempt to provide a long-term view of the basin filling.

Apart from testing the hypothesis linking sea-level change to sediment instability, the drilling has provided a record of the volumes of sediment reworked from the continental margin and island flanks through time, thus enabling calculations of sediment budgets for the whole Canary Basin. This approach to basin analysis is unique, and we believe more productive than trying to determine the mass-wasting events at their source, as these sources may extend along an extensive continental margin where many drill sites would be needed to sample every event.

By drilling the products of each mass-wasting event, we circumvent the problem of correlating erosive events between adjacent drill sites. If such events occur every few tens of thousands of years, but the accuracy of biostratigraphic dating is in the order of tens to hundreds of thousands of years, then it is not possible to determine if correlations of closely spaced events are real or not. In erosive areas, this problem is compounded because the sediment on top of a mass flow deposit or immediately above a hiatus may have accumulated long after the event. On the abyssal plain, each event can be clearly distinguished from the one above and below, because each represents a separate depositional event. Turbidity currents entering the MAP do not cause significant erosion (Weaver and Kuijpers, 1983), and the area is not swept by strong currents nor subject to any other form of erosion.

Basin analysis, using abyssal plain sequences, has not been attempted before by the Deep Sea Drilling Project or the Ocean Drilling Program (ODP). In fact, abyssal plains have not been targeted for drilling very often, although they have been drilled when they overlay basement objectives such as during ODP Leg 123 (Argo Abyssal Plain) and Leg 149 (Iberia Abyssal Plain). Turbidites from the Argo Abyssal Plain are similar to those from the MAP, with individual turbidites ranging from a few centimeters to several meters in thickness and consisting predominantly of mud with some coarser bases. They are separated by thin pelagic layers (Ludden, Gradstein, et al., 1990). In the Iberia Abyssal Plain, Sites 897, 898, and 899 were all drilled at the edge of the plain. They reveal turbidites of a few centimeters to a few meters in thickness, in some cases with sandy bases, separated by pelagic layers (Milkert et al., 1996).

Turbidites closely resembling those of the MAP have been identified in the Seine Abyssal Plain, northwest of Morocco (Davies et al., 1997). This basin has a maximum water depth of $4400 \mathrm{~m}$ and is separated from the Canary Basin by a low sill in its southwest corner. The sill rises $\sim 100 \mathrm{~m}$ above the abyssal plain floor, and there is some evidence that larger turbidity flows spill over into the Canary Basin and flow down the continental rise to the MAP. Two other abyssal plains on the Iberian margin, the Horseshoe and Tagus, show very frequent input of muddy turbidites. These flows characteristically have thicker sandy bases toward the east near their entry points onto the plain (Lebreiro et al., 1997).

\section{GEOPHYSICAL SETTING}

The Canary Basin covers an area of $3.36 \times 10^{6} \mathrm{~km}^{2}$ (Rothwell et al., 1992) and is bounded by the lower flank of the Mid-Atlantic
Ridge (MAR) in the west, the Azores-Gibraltar Rise (part of the European/African Plate boundary) in the north, the Madeira-Tore Rise in the northeast, and the Cape Verde Rise in the south. This basin includes the Canary Islands and Madeira together with the Cruiser/ Hyères/Great Meteor seamount chain (von Rad, 1974) in the west, as well as a $1500 \mathrm{~km}$ stretch of the northwest African margin.

The MAP lies in the deepest part of the Canary Basin at a water depth of $5400 \mathrm{~m}$ and occupies a 400 (north-south) $\times 200$ (east-west) $\mathrm{km}$ area (Fig. 1). The abyssal plain is bounded by hills to the west, south, and north, and by a sharp change of slope to the east, from the very gentle gradient of the rise $(\sim 1: 300$ to $1: 1000)$ to the virtually flat $(<1: 3000)$ abyssal plain (Searle, 1987). The Charis and Cruiser Fracture Zone Valleys extend westward from the plain between the hills of the MAR flank. Locally, the abyssal plain is interrupted by abyssal hills a few hundred meters high and a few tens of kilometers across, nearly all draped by hemipelagic sediment (Fig. 1). This hemipelagic drape averages $200 \mathrm{~m}$ in thickness. Turbidites have infilled this draped topography, lying conformably on the drape in the deeper parts of the basins, but resting with a clear unconformity where the hills rise up steeply (Fig. 2). The turbidite sequence averages $350 \mathrm{~m}$ in thickness, except in a few deep areas, where it may reach $530 \mathrm{~m}$, and it varies from being strongly acoustically laminated near the top to poorly stratified to transparent near the base (Duin and Kuijpers, 1983).

\section{AGE DETERMINATIONS}

The production of an accurate stratigraphy is essential to the interpretation of the amount of sediment contributed to the abyssal plain from each source through the Neogene. This has been achieved principally through nannofossil studies, supported by paleomagnetic reversal stratigraphy in the APC cores ( the upper $150 \mathrm{~m}$ ). Where possible, carbonate rich pelagic layers were sampled to provide the stratigraphy. Pelagic layers with nannofossils were extremely rare below the base of the Pliocene, however, because of a higher carbonate compensation depth (CCD) at this time. Through the Miocene, it was thus necessary to sample the turbidites to obtain biostratigraphic data, and these were found to give very useful stratigraphic information. Where possible, the first occurrences of species were used, because these events are not affected by reworking. However, Weaver (1994) showed that the organic and volcanic turbidites in the Canary Basin were formed by erosion of only the upper few tens of meters of the sediment column, representing 50-500 k.y. of deposition. Hence, even ages for last occurrences determined from these flows should be accurate to 50-500 k.y. Howe and Sblendorio-Levy (Chap. 29, this volume) have shown that all the nannofossil zones can be recognized in the turbidite sequence, and that these are all in stratigraphic order. The accumulation rate curves for each site also provide a very plausible pattern with no erratic rate changes. We, therefore, believe that the stratigraphy for each MAP site is accurate within the limitations of any biostratigraphic scheme. Ages given in this paper were derived from the accumulation rate graphs produced by Howe and Sblendorio-Levy (Chap. 29, this volume).

\section{SEISMIC STRATIGRAPHY}

Research on the MAP during the 1980s provided a network of $8000 \mathrm{~km}$ of single-channel seismic lines (Searle, 1987). Interpretation of these has provided a seismic stratigraphy for the whole plain within which a number of seismic units can be recognized. These include an upper unit (A) with high-amplitude reflectors that onlap onto the basement highs, but become almost horizontal away from these highs, and a lower unit (B) that drapes the basement. The upper unit can be subdivided into an upper subunit (A1) with strong reflectors, a middle unit (A2) with a transparent top and three strong reflectors beneath, and a lower subunit (A3) with weaker reflectors. 


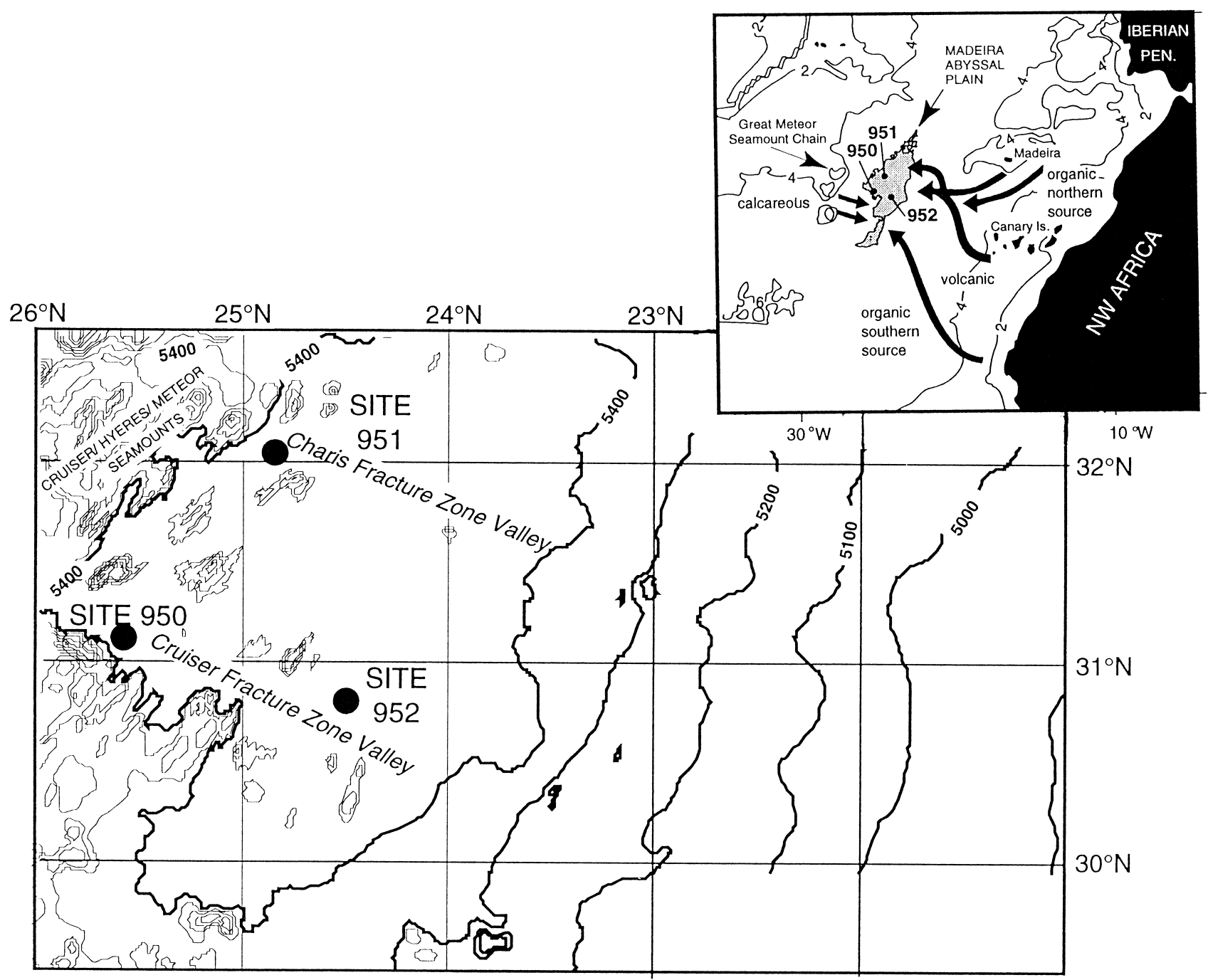

$40^{\circ} \mathrm{N}$

Figure 1. Detailed bathymetry of the Madeira Abyssal Plain, showing positions of drill sites. Contour interval = $100 \mathrm{~m}$; approximate limit of abyssal plain marked by 5400-m contour. Inset shows the Canary Basin. Note main sources of turbidites are around the northwest African margin, the Canary Islands, and the seamounts to the west of the abyssal plain.

All three drill sites were located on crossing seismic lines, at positions where the sequence is well developed. At Site 950, drilling proceeded through seismic Unit A into seismic Unit B, whereas at Sites 951 and 952 drilling was terminated in Unit A3. Velocity profiles for Sites 950 and 951 were used by Rothwell et al. (Chap. 28, this volume) to calculate the thickness of each seismic unit and to approximate their boundaries in the core material. They also used the extensive seismic coverage to estimate the total area and volume of each seismic unit. As a final step, the thicknesses of each sedimentary unit were decompacted and the volumes of each seismic unit recalculated (Table 1). These data can now be integrated with the stratigraphic data to show the volume of sediment eroded from the source areas since the inception of the plain.

\section{PRINCIPAL RESULTS OF THE DRILLING}

The three sites drilled into the turbidite sequence on the MAP were all located in infilled fracture zone valleys. These valleys were chosen because they have always had an open connection to the continental rise to the east and thus should contain the most complete turbidite sequences. Sites 950 and 952 are $65.5 \mathrm{nmi}$ apart in the Cruiser Fracture Zone Valley, and Site 951 lies $59 \mathrm{nmi}$ to the north-northwest of Site 950 in the Charis Fracture Zone Valley (Fig. 1). At all sites, the sediments are dominated by thick turbidites (commonly $0.5-3 \mathrm{~m}$ thick), separated by thinner pelagic layers.

\section{Variation in the CCD}

Weaver and Kuijpers (1983) showed that incoming turbidity currents caused little erosion of the seabed. The pelagic sediment record between successive turbidites is therefore complete and can be reconstructed by eliminating the turbidite units. The MAP lies at $5400 \mathrm{~m}$ water depth, within the lysocline, but above the present day CCD. At this depth, in one of the deepest basins in the North Atlantic, pelagic deposits reflect changes through time in the depth of the CCD. The composition of the pelagic units is not difficult to interpret because oozes are white, clays are red-brown, and marls have an intermediate color. Samples for analysis were taken away from lithologic boundaries where bioturbation may have mixed two lithologies. At Site 950 , the deeper part of the sequence from $333 \mathrm{~m}$ (23.7 Ma) to the base of the hole at $371.6 \mathrm{~m}(\sim 36.6 \mathrm{Ma})$ is represented by red clay with interbedded thin calcareous turbidites and zeolitized ash. Above this, all pelagic interbeds are of red clay, devoid of $\mathrm{CaCO}_{3}$, until 235 meters below seafloor (mbsf; $\sim 8 \mathrm{Ma}$ ). From 8 to $6.5 \mathrm{Ma}$, some of the pelagic units contain $10 \%-20 \% \mathrm{CaCO}_{3}$, whereas others are devoid of 

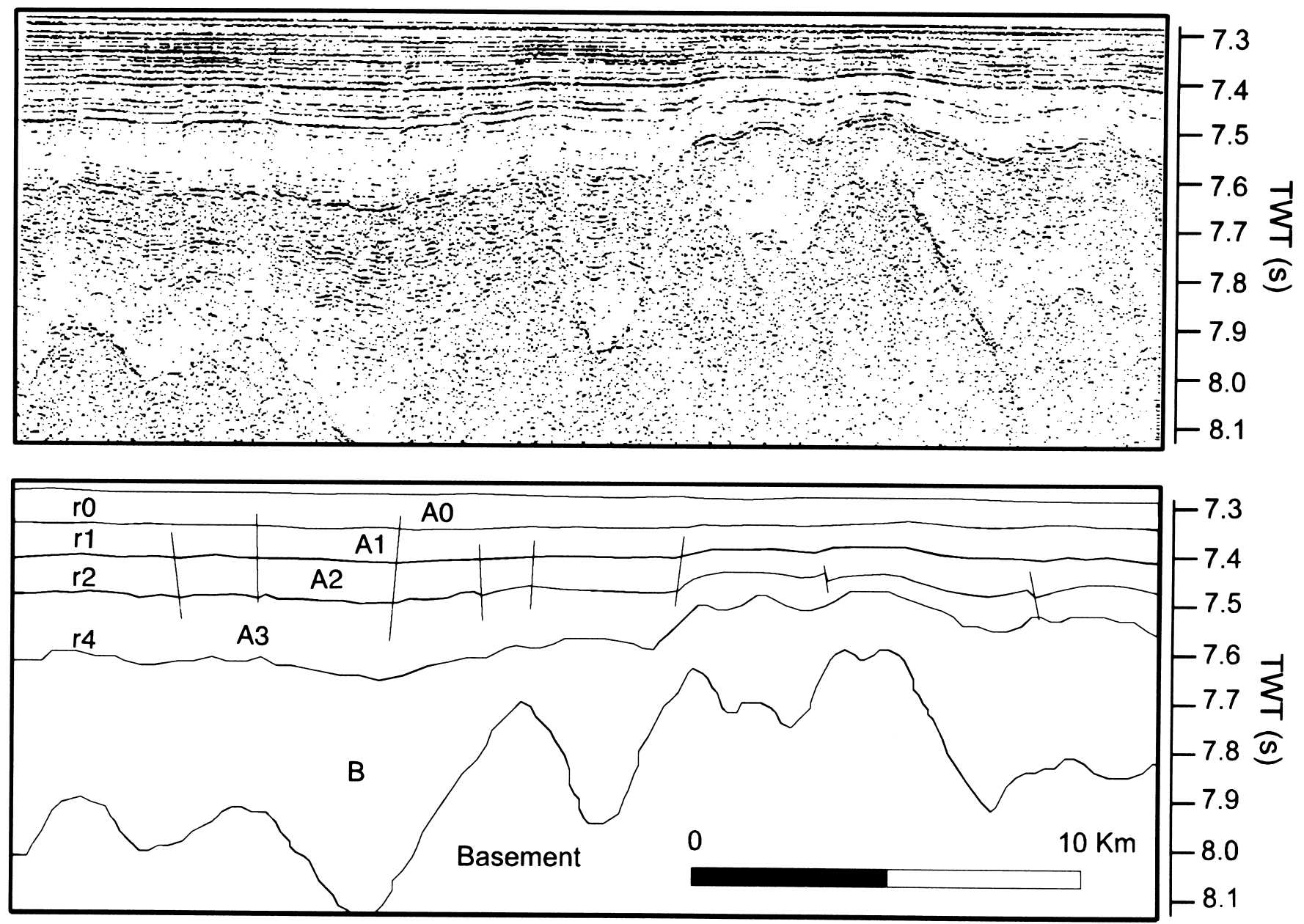

Figure 2. Typical seismic profile showing basement draped by pelagic sediments (seismic Unit B) and parallel-laminated infilling turbidites. Note subdivision of turbidite sequence into upper strongly laminated interval (seismic Units A0 and A1) and lower transparent interval (seismic Units A2 and A3).

Table 1. Integration of seismic data with turbidite thickness measurements from drill sites.

\begin{tabular}{|c|c|c|c|c|c|c|c|}
\hline Seismic unit & & $\begin{array}{l}\text { Organic } \\
\text { turbidites }\end{array}$ & $\begin{array}{l}\text { Volcanic } \\
\text { turbidites }\end{array}$ & $\begin{array}{l}\text { Gray nonvolcanic } \\
\text { turbidites }\end{array}$ & $\begin{array}{l}\text { Calcareous } \\
\text { turbidites }\end{array}$ & $\begin{array}{l}\text { Brown } \\
\text { turbidites }\end{array}$ & Totals \\
\hline & & \multicolumn{6}{|c|}{ Average percentages } \\
\hline A0 & & 44 & 25 & 13 & 7 & 0 & 89 \\
\hline A1 & & 55 & 16 & 1 & 9 & 0 & 82 \\
\hline A2 & & 50 & 12 & 18 & 9 & 1 & 90 \\
\hline \multirow[t]{2}{*}{ A3 } & & 51 & 11 & 8 & 9 & 3 & 83 \\
\hline & Seismic unit volumes* & \multicolumn{5}{|c|}{ Volumes per seismic unit $\left(\mathrm{km}^{3}\right)$} & \\
\hline A0 & 2,380 & 1,054 & 586 & 320 & 164 & 0 & \\
\hline A1 & 2,386 & 1,318 & 390 & 32 & 213 & 9 & \\
\hline A2 & 2,340 & 1,175 & 276 & 425 & 215 & 26 & \\
\hline A3 & 4,480 & 2,287 & 504 & 348 & 422 & 135 & \\
\hline \multirow[t]{2}{*}{ Total: } & 11,586 & 5,834 & 1,757 & 1,125 & 1,014 & 170 & \\
\hline & Compaction corrected volume* & \multicolumn{5}{|c|}{ Volumes per seismic unit $\left(\mathrm{km}^{3}\right)$, corrected for compaction } & \\
\hline A0 & 3,060 & 1,355 & 754 & 412 & 210 & 0 & \\
\hline A1 & 3,690 & 2,038 & 604 & 49 & 329 & 14 & \\
\hline A2 & 4,270 & 2,144 & 504 & 775 & 393 & 48 & \\
\hline A3 & 8,160 & 4,166 & 919 & 634 & 769 & 246 & \\
\hline \multirow[t]{2}{*}{ Total: } & 19,180 & 9,703 & 2,780 & 1,870 & 1,701 & 308 & \\
\hline & Duration (m.y.) & \multicolumn{5}{|c|}{ Rate of accumulation $\left(\mathrm{km}^{3} / \mathrm{m} . \mathrm{y}.\right)$, corrected for compaction } & \\
\hline A0 & 1.6 & 847 & 471 & 257 & 131 & 0 & \\
\hline A1 & 1.9 & 1,073 & 318 & 26 & 173 & 8 & \\
\hline A2 & 2.5 & 858 & 202 & 310 & 157 & 19 & \\
\hline A3 & 10.0 & 417 & 92 & 63 & 77 & 25 & \\
\hline
\end{tabular}

Notes: $*$ Rothwell, et al. (Chap. 28, this volume). Average percentages refer to the average for Sites 950, 951, and 952 of the percent of each turbidite type in each seismic unit (the totals fall short of $100 \%$ due to pelagic layers and intervals of no recovery). The percentages are then applied to the volumes of each seismic unit in compacted and decompacted form as defined by Rothwell et al. (Chap. 28, this volume). The estimated age of each reflector is used to determine the rate of sediment accumulation per seismic unit. 
$\mathrm{CaCO}_{3}$. From 6.5 to $5 \mathrm{Ma}$, the $\mathrm{CaCO}_{3}$ content of the pelagic layers ranges from $1 \%$ to $10 \%$, and above this, there is a sharp rise to $10 \%-$ $20 \% \mathrm{CaCO}_{3}$, which lasts from 5 to $3.5 \mathrm{Ma}$. At $3.5 \mathrm{Ma}$, large fluctuations in $\mathrm{CaCO}_{3}$ values begin with these values ranging from almost $0 \%$ to $70 \%$ between 3.5 and $1.9 \mathrm{Ma}$. From 1.9 to $0.45 \mathrm{Ma}$, there is an interval of increased $\mathrm{CaCO}_{3}$ preservation during which a series of oozes with values over $80 \%$ were deposited interspersed with marls of $20 \%-40 \% \mathrm{CaCO}_{3}$. From $0.45 \mathrm{Ma}$ to the present, marls of $40 \%-$ $70 \% \mathrm{CaCO}_{3}$ are interlayered with clays of $<20 \% \mathrm{CaCO}_{3}$.

The MAP, therefore, lies beneath the CCD from at least the Eocene until the late Miocene ( $8 \mathrm{Ma}$ ), at which time a few incursions of less corrosive bottom water appear to have entered the basin. These, however, were short lived and are interspersed with periods of corrosive bottom water. From 6.5 to $5 \mathrm{Ma}$, the area lay just above the $\mathrm{CCD}$ with a small amount of $\mathrm{CaCO}_{3}$ preservation, after which preservation improved, indicating continuous less corrosive bottom water that lasted until the abrupt change at 3.5 Ma. From 3.5 Ma to the present, the bottom waters have alternated dramatically and frequently between more and less corrosive. The CCD was at its deepest during interglacials between 1.9 and $0.45 \mathrm{Ma}$. A plot of $\mathrm{CaCO}_{3}$ data from the pelagic layers of Hole 950A shows the CCD variation through the last 17 Ma (Fig. 3).

\section{Turbidite Sediments}

\section{Geochemistry}

The geochemistry of Miocene to Pleistocene MAP turbidites has been studied in detail (Jarvis et al., Chap. 31, this volume) at Site 950. Here, significant turbidite deposition began in the early Miocene with the deposition of thin carbonate-sand turbidites and three thick carbonate debris flows. These beds have distinctive trace-element-enriched geochemical signatures reflecting the incorporation of significant amounts of basaltic material and shallow-water carbonate grains derived from the erosion of seamounts lying to the west of the plain.

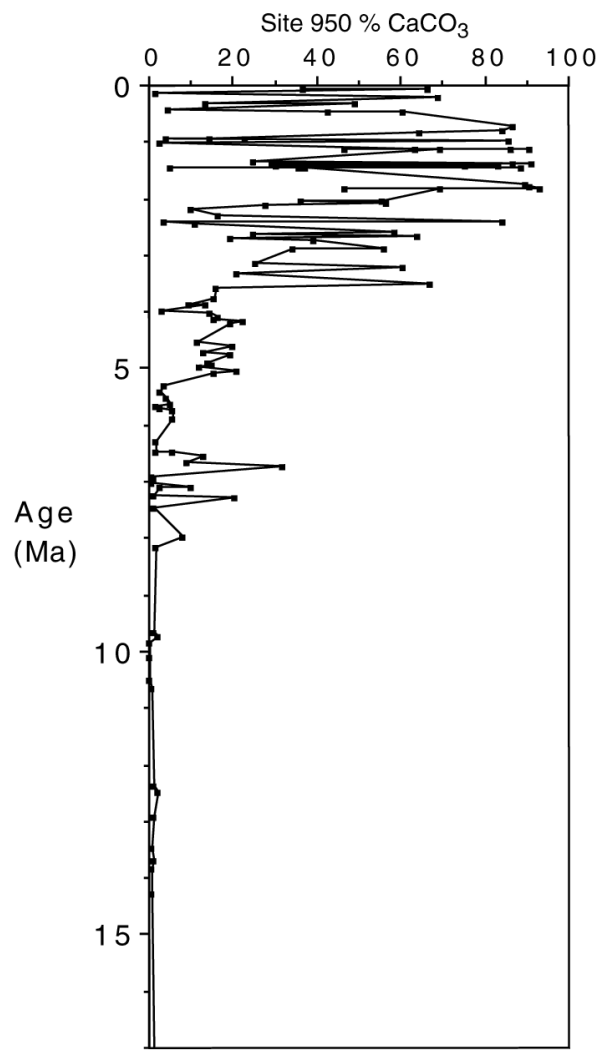

Figure 3. Calcium carbonate percentages for Site 950 plotted against time.
Above this, the middle Miocene to Pleistocene is dominated by the deposition of distal mud turbidites, which began $15 \mathrm{Ma}$. Geochemical data for these beds (Fig. 4) demonstrate that the three main Quaternary turbidite groups continue down to the middle Miocene at Site 950; elsewhere on the plain, organic-rich beds continue to occur in fracture zone valleys (Sites 951 and 952) into at least the lower Miocene (Schmincke, Weaver, Firth, et al., 1995; Lebreiro et al., Chap. 30, this volume).

Organic-rich turbidites dominate the sedimentary record (Fig. 4) and become progressively more $\mathrm{K}$ and $\mathrm{Mg}$ rich upward (Jarvis et al., Chap. 31, this volume). Three subgroups are evident from the geochemical data, indicating significant changes in sediment sources, particularly during the early late Miocene (10-11 Ma), with a shift toward more potassic (illitic and chloritic) and carbonate-rich compositions, and during the latest early Pliocene $(\sim 3.5 \mathrm{Ma})$, with the disappearance of very low-K (kaolinite-rich), carbonate-poor turbidites. The high-K subgroup probably originated from a northern source area on the upper continental slope off Morocco, whereas high-Al sediments were derived from the south, off Western Sahara. Climatic changes are also likely to have modified sediment mineralogy in the competing source areas.

Volcanic turbidites are volumetrically the second most important sediment type through most of the sequence at all three MAP sites (Jarvis et al., Chap. 31; Lebreiro et al., Chap. 30, both this volume). Although best defined by their high Ti:Al ratio (Fig. 4), volcanic turbidites are also generally characterized by high magnetic susceptibility (Lebreiro et al., Chap. 30, this volume), caused by the presence of volcanic material including pyroxenes, lithic grains, and glass shards. The first typical thick-bedded, Ti-, Fe-, and Zr-rich volcaniclastic turbidites with high magnetic susceptibility were deposited on the MAP in the mid- to late Miocene $\sim 6.5 \mathrm{Ma}$, and probably originated from the Canary Island slopes of Gran Canaria or Lanzarote. A major change to common turbidites with very high $\mathrm{Ti}$ and Fe contents (Fig. 4 ), reflecting the dominance of more basaltic source areas, occurred around the beginning of the late Pliocene ( $3.5 \mathrm{Ma})$, possibly associated with sediment failure during the early growth of La Palma. Younger volcanic turbidites display a clear trend toward less Ti-rich compositions (Fig. 4), indicating derivation from the vicinity of progressively more fractionated volcanic sources since 3.5 Ma. Howev-

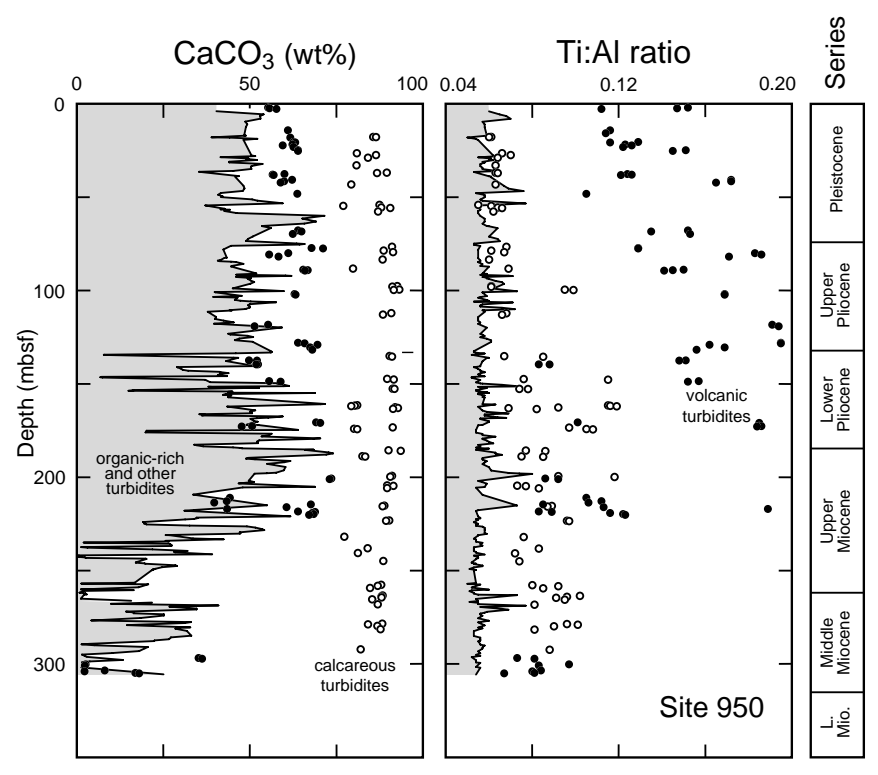

Figure 4. Geochemical variation in turbidite carbonate contents and Ti:Al ratios, Site 950. Note the clear distinction between volcanic (solid circles), calcareous (open circles), organic-rich and other (shaded area and continuous line) turbidites (after Jarvis et al., Chap. 31, this volume). 
er, despite this overall trend, a wide range of trace-element compositions suggest a continued supply from a variety of different source areas on the Canary Island slopes from that time. A thin package of thinly bedded, dark gray volcanic turbidites with distinctive low-Ti, trace-element-depleted geochemical signatures (Fig. 4) and low magnetic susceptibility was deposited during the early middle Miocene (15-17 Ma). These are of uncertain affinity, but must have been derived from the vicinity of an evolved volcanic source, possibly the slopes of the Canary Islands off Lanzarote or Gran Canaria.

Thin-bedded calcareous turbidites occur throughout the sequence (Schmincke et al., 1995; Jarvis et al., Chap. 31; Lebreiro et al., Chap. 30 , both this volume). They originated predominantly from the seamount chains to the west of the MAP and, up until the late Pliocene, have high Ti:Al ratios (Fig. 4), reflecting the incorporation of a significant proportion of basaltic material derived from erosion of the exposed volcanic edifices. Since $\sim 3.5 \mathrm{Ma}$, these seamounts have been largely covered by a pelagic sediment drape, which now provides the main sediment source for calcareous turbidites on the plain.

\section{Sedimentology}

Lebreiro et al. (Chap. 30, this volume) divided the turbidites into four main types. These are broadly similar to those defined by the geochemistry, but the gray nonvolcanic turbidites are regarded as a subgroup of the volcanic turbidites, and an additional group of brown turbidites is added. The groups include the following:

1. Olive green, organic carbon-rich turbidites, frequently with pale green oxidized tops and distinctive redox fronts. These vary from deep olive green to pale green with the paler units having higher $\mathrm{CaCO}_{3}$ and less $\mathrm{C}_{\text {org }}$ contents. The calcium carbonate content varies from $0 \%$ to $40 \%$ before 6.5 Ma to $30 \%$ to $60 \%$ from $6.5 \mathrm{Ma}$ to the present in each of the sites. They have low magnetic susceptibility values. Previous work has shown that these turbidites were derived from the northwest African continental margin (Weaver et al., 1992).

2. Gray volcanic rich turbidites. These do not contain oxidation fronts. They have calcium carbonate contents of $40 \%-80 \%$ in the interval 0-7 Ma and somewhat lower $\mathrm{CaCO}_{3}$ contents before $7 \mathrm{Ma}$. Most of these turbidites have high magnetic susceptibility values, but a small number are peculiar in that they have low magnetic susceptibility values. They derive principally from the Canary Islands, although it is possible that some are also derived from Madeira. The turbidites with low magnetic susceptibility values may have a different source.

3. Calcareous turbidites. These have calcium carbonate values above $75 \%$ and are derived from the Hyères/Cruiser/Great Meteor seamount chain to the west of the MAP. Near the base of the turbidite sequence at 16 and $17 \mathrm{Ma}$ at Site 950 are two thick calcareous turbidites with coarse sandy bases containing shallow-water faunas (Brunner and Maniscalco, Chap. 7, this volume).

4. Brown turbidites. These have variable $\mathrm{CaCO}_{3}$ contents $(5 \%-$ $70 \%$ ) and moderately high magnetic susceptibilities. They are most common at Site 950, where they are limited to between 215-272 mbsf (6.5-12 Ma). We interpret their composition and distribution to indicate a source on the Hyères/Cruiser/ Great Meteor seamount chain to the west. During periods of shallow CCDs, the lower flanks of these seamounts may have been draped by pelagic clays that were replaced after $\sim 6.5 \mathrm{Ma}$ by pelagic oozes, thus replacing the brown turbidites with calcareous ones.

5. Other turbidites. Two volcaniclastic sand-silt turbidites were recovered at the base of Hole 950A (late Eocene age). They were probably derived from the Hyères/Cruiser/Great Meteor seamount chain when these seamounts were subaerial, active volcanoes. A number of thin brown turbidites are interspersed with volcanic ash layers through the late Eocene and Oligocene at Site 950 . These are again presumed to have been derived from the seamounts to the west.

\section{THE TURBIDITE SEQUENCE}

We have used the lithologic subdivision of turbidite and pelagic units provided by Lebreiro et al. (Chap. 30, this volume), backed up by the geochemical analyses of Jarvis et al. (Chap. 31, this volume), together with the stratigraphic data of Howe and Sblendorio-Levy (Chap. 29, this volume) to plot the distribution of each turbidite type through time. To facilitate this, we used the biostratigraphic data to subdivide the sequence at each site into 0.5-m.y. time slices. We used the lithologic correlations of individual beds to identify anomalies in the dating and to ensure a rigid stratigraphic framework. The thicknesses of each turbidite type and the pelagic layers were then calculated for each time slice. The data are displayed in Figures 5-7, which provide a very detailed and unique record of the infilling of a deepsea basin. The accumulation rates are strongly affected by compaction in the upper part of the sediment column. This has been accounted for in our calculations of mass sediment flux in which the bulk density is used to correct for water content. The total sediment flux of each turbidite type is shown in Figure 6.

\section{Correlation of Individual Turbidites}

One of the remarkable features of the MAP sediments is the ease with which individual turbidite units can be correlated between cores. Piston core data showed that all the major flows could be correlated across the whole plain, and minor flows could be correlated between adjacent cores within a limited area (Weaver et al., 1995). We have also been able to correlate all the major flows between the three drill sites (see Lebreiro et al., Chap. 30, this volume). The process is aided by identification of a number of marker beds distinguished by unusual composition or thickness and by micropaleontological backup (Howe and Sblendorio-Levy, Chap. 29, this volume). Turbidites older than $13 \mathrm{Ma}$ at each site were very different, and correlations were not possible, with the exception of the Cruiser Turbidite, a thick and distinctive flow that appears to have deposited across the whole plain.

\section{Turbidite Depositional History}

\section{6-40 Ma}

This part of the sequence was drilled only at Site 950. The oldest turbidites are the volcanic sandstones of Eocene age drilled in Hole $950 \mathrm{~A}$ that were derived from the Hyères/Cruiser/Great Meteor Seamount Chain to the west. Following this, there was a long period of pelagic clay deposition (average accumulation rates of $2.4-4.1 \mathrm{~m} /$ m.y.), with only a few very thin brown turbidites deposited until $\sim 26$ Ma. This pelagic clay belongs to seismic Unit B and represents draped sediments over the basement. From 26 to $17 \mathrm{Ma}$, there is a hiatus at Site 950.

\section{$17-13 \mathrm{Ma}$}

This interval includes the first green organic turbidites derived from the northwest African margin to reach Site 950, and shows the final infilling of the fracture zone valleys at Sites 951 and 952. The hiatus from 26 to $17 \mathrm{Ma}$ at Site 950 is succeeded by three thick calcarenites from the seamount chain to the west (Figs. 6, 7). The youngest of these is the thickest $(10.5 \mathrm{~m})$ and has been named the Cruiser Turbidite after the seamount that was its probable source. It has an emplacement age of $16 \mathrm{Ma}$. Higher accumulation rates prevented drilling at Sites 951 and 952 from reaching all three flows, but the up- 
NW AFRICAN ORIGIN
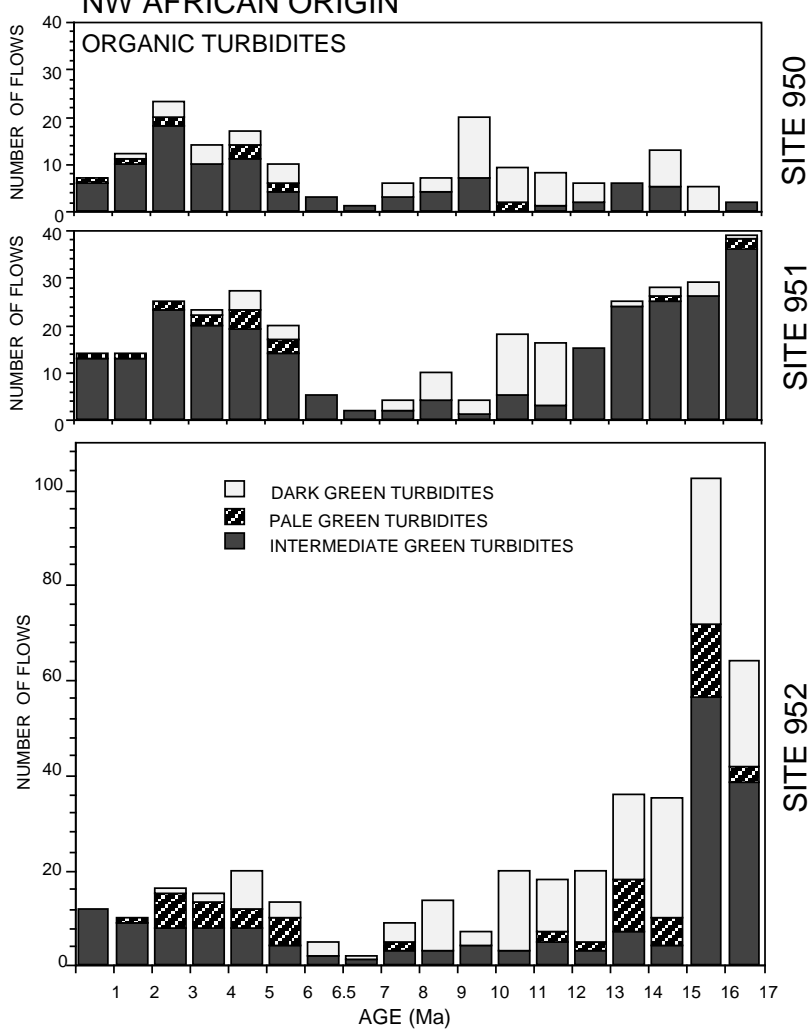

SEAMOUNTS TO THE WEST
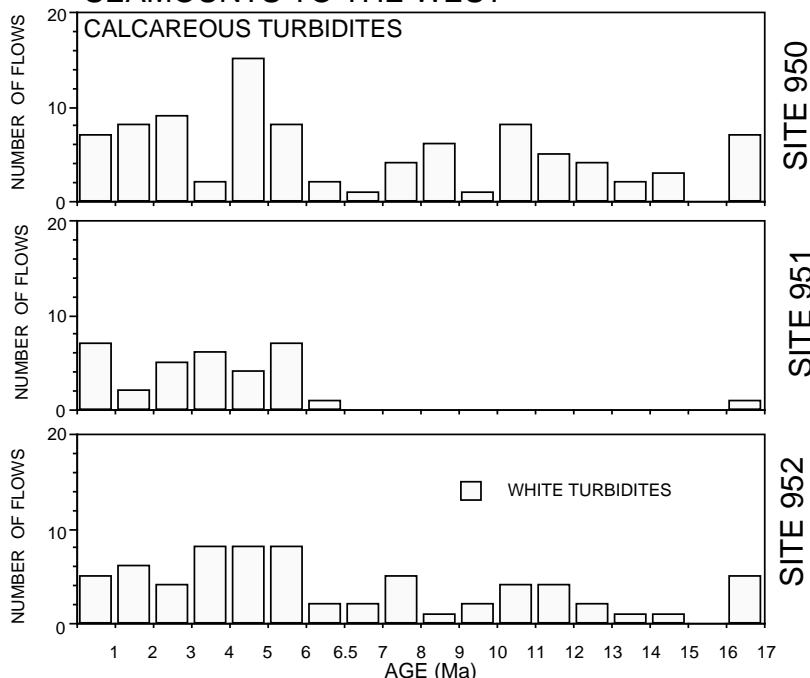

CANARY ISLANDS
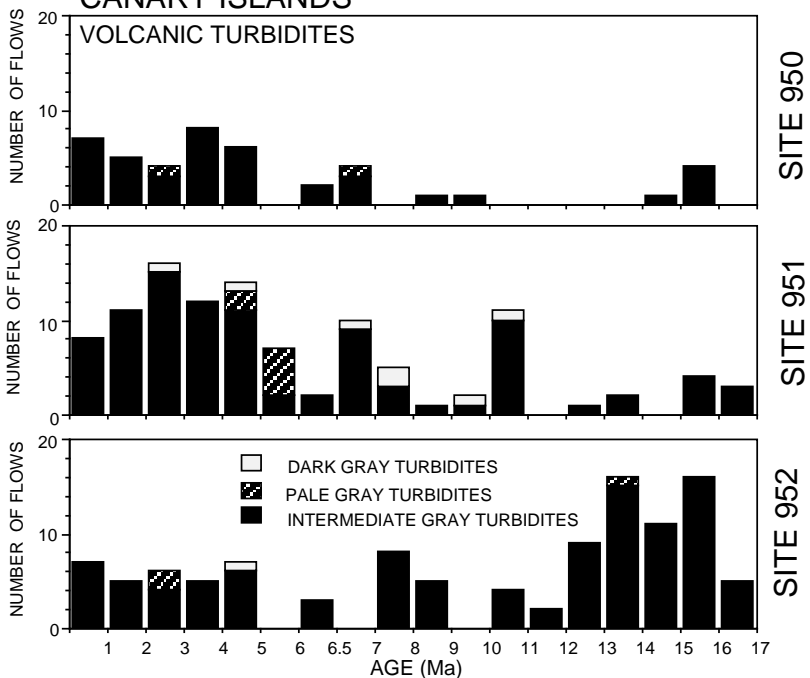

CANARY ISLANDS ?
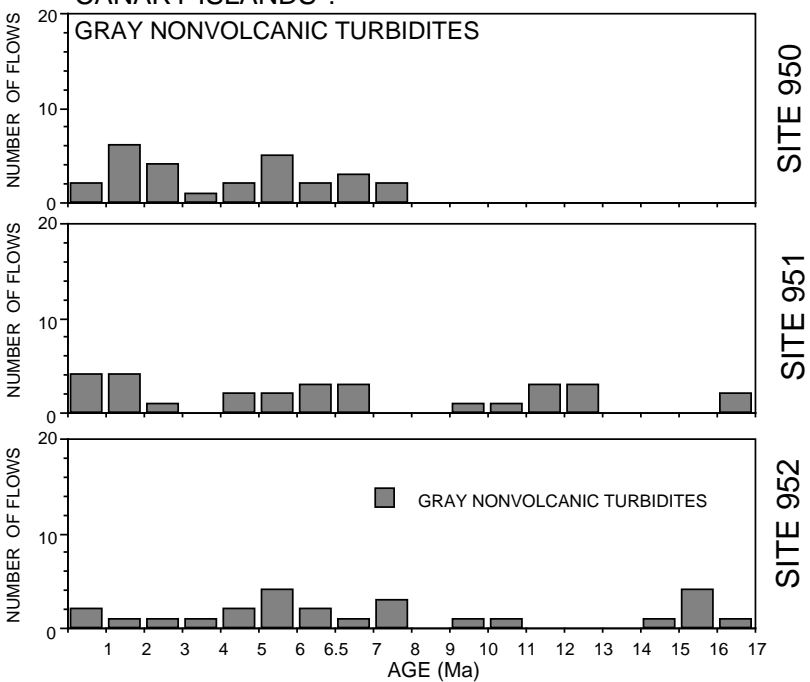

SEAMOUNTS TO THE WEST

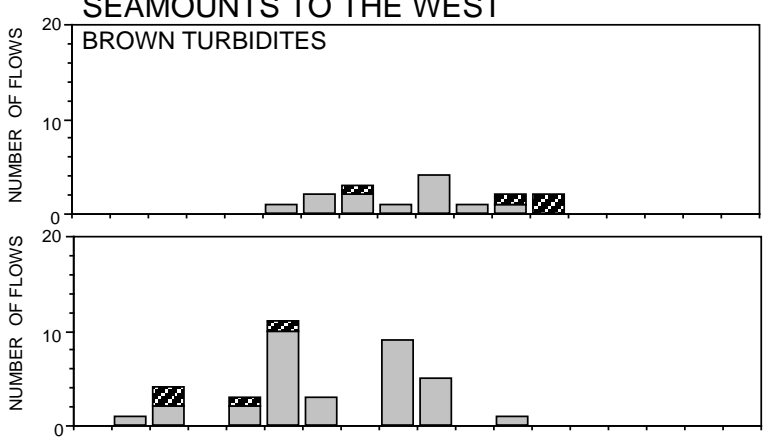

윰
ㅂ
c

亡্ণ

㟶

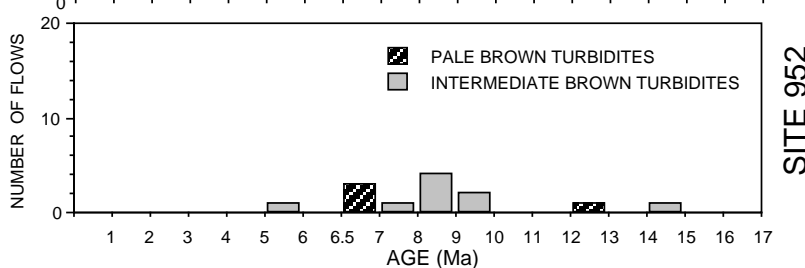

Figure 5. Number of turbidites of each type deposited per million-year timeslice at Sites 950, 951, and 952. The 6- to 7-m.y. timeslice is divided into two halfmillion-year intervals to show the sharp change in accumulation rates at 6.5 Ma. Turbidite information from Lebreiro et al. (Chap. 30, this volume), ages from Howe and Sblendorio-Levy (Chap. 29, this volume). 

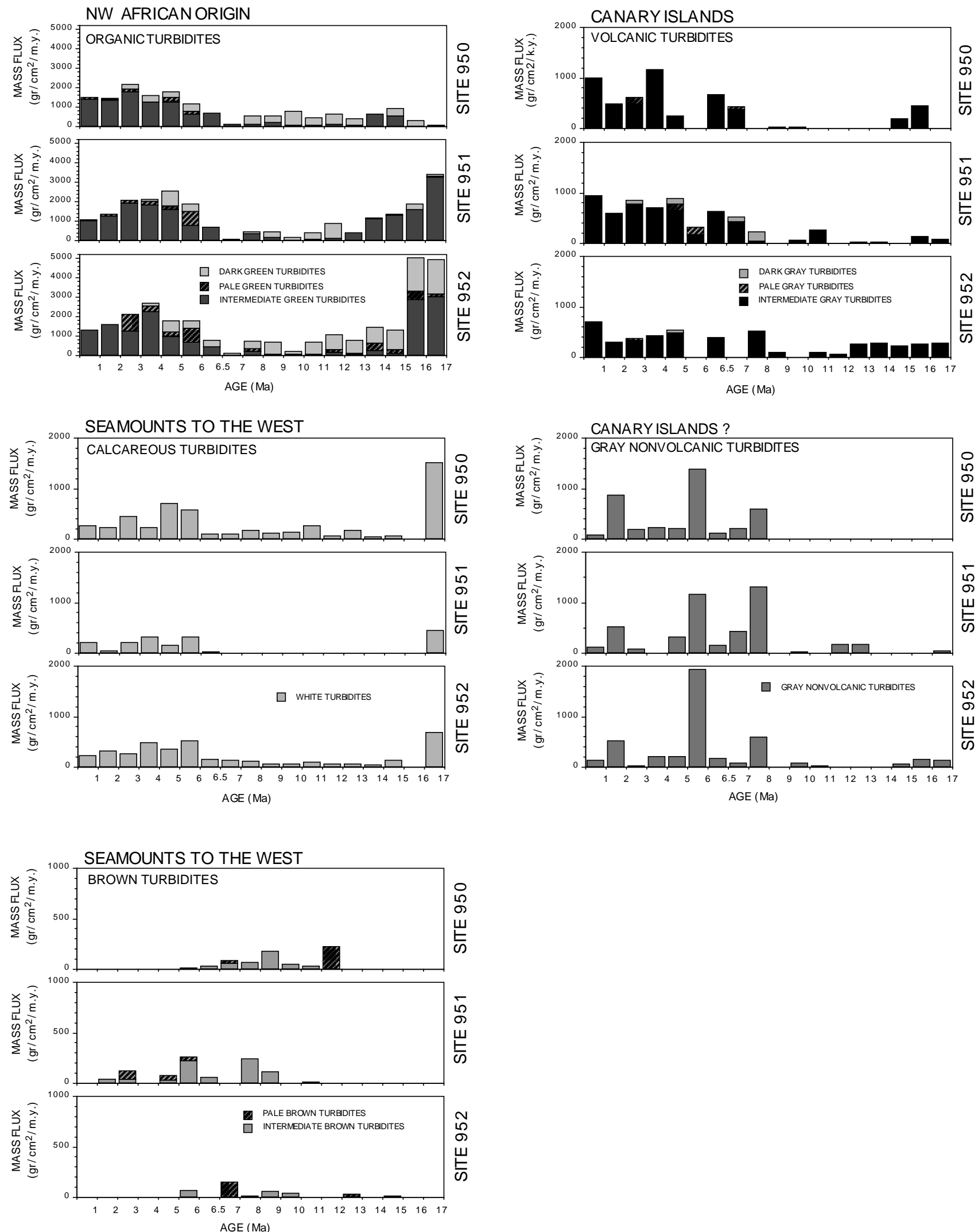

Figure 6. Mass sediment flux of each turbidite type for Sites 950, 951, and 952. The 6- to 7-m.y. timeslice is divided into two half-million-year intervals to show the sharp change in accumulation rates at $6.5 \mathrm{Ma}$. 

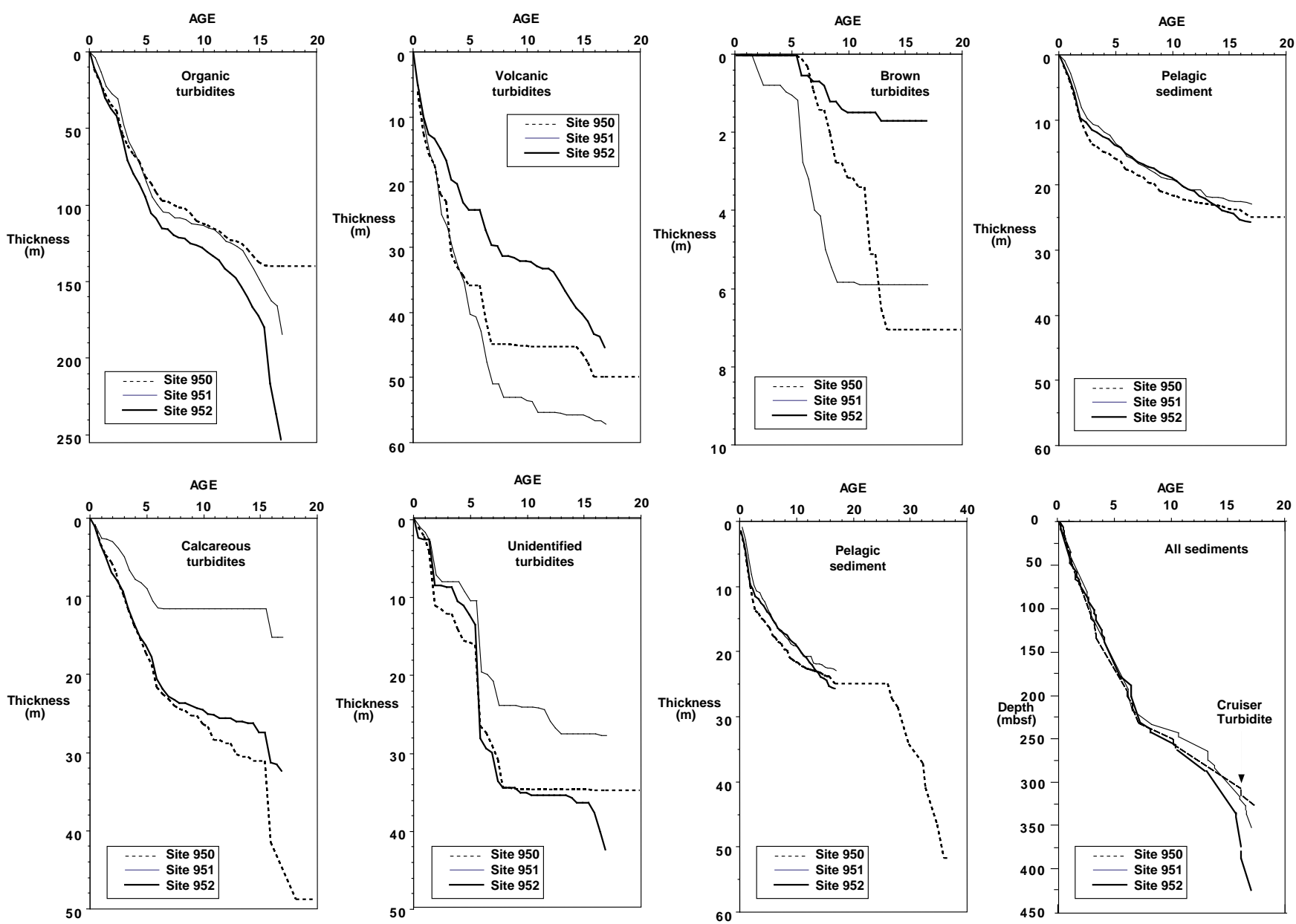

Figure 7. Accumulation rates for each turbidite type at Sites 950, 951, and 952. Data produced by summing the total thickness of each turbidite type; age data from Howe and Sblendorio-Levy (Chap. 29, this volume).

per flow was recovered at all sites (Fig. 7). The Cruiser Turbidite appears to cause the major seismic reflector R4, which can be traced across the whole plain, in most areas forming the boundary between pelagic drape beneath and turbidites above (seismic Units B and A, respectively). An exception to this is in the fracture zone valleys where turbidites appear to continue beneath reflector R4.

Sites 951 and 952 are located in the Cruiser and Charis Fracture Zone Valleys, respectively. Below the Cruiser Turbidite, they show thick sequences of organic turbidites deposited with the greatest frequency (up to 100 flows/m.y.) and highest rates of accumulation (up to $48 \mathrm{~m} / \mathrm{m}$.y.; Figs. 5, 7) in the whole sequence. Both Sites 951 and 952 show higher accumulation rates than Site 950 before $~ 13 \mathrm{Ma}$, after which all three sites have similar accumulation rates. We believe that these changes reflect the early infilling of the fracture zone valleys. Figures 5 and 7 show this infilling to be caused by numerous and very frequent small flows from the northwest African margin. The areas over which these early turbidites could be deposited were limited to the narrow valleys themselves, which have a combined area of $5700 \mathrm{~km}^{2}(\sim 15 \%$ of the total area of the plain). Within these valleys, they deposited $\sim 1700 \mathrm{~km}^{3}$ of sediment as a wedge narrowing to the base (Searle, 1987). Because of the "V" shape of the valleys, earlier flows would have had a much smaller area over which to deposit and thus the same volume of sediment would have produced a thicker unit, giving rise to even higher accumulation rates. Only a few million years therefore were required to fill the fracture zone valleys completely. By $\sim 16 \mathrm{Ma}$, the valleys had almost filled so that the Cruiser Turbidite was deposited across the whole plain. Between 15 and $13 \mathrm{Ma}$, the number and total thickness of organic turbidites de- posited at Sites 951 and 952 declined to match the level deposited at Site 950, suggesting late stage infilling of the fracture zones. It may be that the final leveling of the plain took until $\sim 13 \mathrm{Ma}$, during which time different numbers and thicknesses of turbidites would have been deposited in different areas. With the exception of the Cruiser Turbidite, it is only after $13 \mathrm{Ma}$ that we can correlate turbidites among the three sites with confidence, suggesting that the flows then covered large areas and were thus of much larger volume than previously.

Deposition during this 13- to 17-Ma interval was dominated by flows from the northwest African margin (Fig. 5). Several small volcanic flows entered the Cruiser Fracture Zone Valley, but only a few were large enough to extend along the valley to Site 950 . Few volcanic flows were deposited at Site 951. Site 952 received several gray nonvolcanic flows between 15 and $17 \mathrm{Ma}$, including a distal debris flow. The pale gray-green nature of these deposits suggests an origin on or near the northwest African margin. During this interval, the western seamounts supplied the Cruiser Turbidite and two previous coarse-grained units. They also supplied a small number of calcareous flows to Site 950 and a lesser number to Site 952, which was located more distally along the Cruiser Fracture Zone Valley. With the exception of the Cruiser Turbidite, no calcareous flows were deposited at Site 951.

\section{$13-6.5 \mathrm{Ma}$}

This interval shows generally low or declining deposition of turbidites from all sources, resulting in the lowest overall accumulation 
rates at each site. The organic turbidites show a general decline in frequency to $<4 / \mathrm{m}$.y. between 6.5 and $7 \mathrm{Ma}$. Volcanic turbidites are rare and thin at all sites, but begin to increase in number and thickness just before $7 \mathrm{Ma}$. The gray nonvolcanic turbidites are very poorly represented until 7.5 Ma to just after $7 \mathrm{Ma}$, during which time several flows were deposited (Figs. 5, 7). Calcareous turbidites are infrequent and thin throughout the interval. A small number of thin brown turbidites were deposited with a different history at each site. We believe these to be derived from erosion of the flanks of the western seamounts, owing to the thicker sequence at Site 950 than at Site 952. The lower flanks of the seamounts would have been below the CCD at this time and thus could have produced these red clay turbidites, while the upper flanks, above the CCD would have produced the calcareous turbidites.

\section{5-0 Ma}

During this interval there was a continuous, high deposition rate of turbidites from most sources. The organic turbidites increase in frequency at $6.5 \mathrm{Ma}$, with an associated increase in accumulation rate from $\sim 6 \mathrm{~m} / \mathrm{m}$.y. to $20 \mathrm{~m} / \mathrm{m}$.y. The increased frequency and accumulation rate of volcanic turbidites, which had begun at $7 \mathrm{Ma}$, continues to the present day. Calcareous turbidites increase in frequency at 6 $\mathrm{Ma}$, and their accumulation rate rises from $\sim 0.4 \mathrm{~m} / \mathrm{m}$.y. to $3.5 \mathrm{~m} / \mathrm{m}$.y. at Sites 950 and 952 . The first calcareous turbidites were deposited at Site 951 at $6 \mathrm{Ma}$. Brown turbidites ceased to be deposited at $5 \mathrm{Ma}$ at Sites 950 and 952 and are much reduced in number and thickness at Site 951 at this time. This may be caused by a progressive lowering of the CCD in the basin which switched deposition on the flanks of the western seamounts from clay to ooze. The gray nonvolcanic turbidites show an unusual pattern with several thick flows deposited between 5.5 and $6 \mathrm{Ma}$ and again between 1.5 and $1.6 \mathrm{Ma}$.

The sediments in the upper part of the sediment column contain the most water, having suffered less compaction. The mass fluxes (where only dry sediment is considered) thus show a slightly different picture from that based on sediment accumulation rates. This is most apparent for the organic turbidites, which show their highest fluxes between 2 and $5 \mathrm{Ma}$, declining somewhat in the last $2 \mathrm{~m}$.y. This reduction is also reflected in the total number of organic turbidites.

The changes in accumulation rates for the various turbidite groups are reflected in the overall accumulation rate for each site by a distinct increase in accumulation at $\sim 6.5-7 \mathrm{Ma}$. Rates increase from $\sim 10$ $\mathrm{m} / \mathrm{m}$.y. between 13 and $6.5 \mathrm{Ma}$ to $\sim 30 \mathrm{~m} / \mathrm{m} . \mathrm{y}$. after $6.5 \mathrm{Ma}$. These changes are associated with a change in seismic signature from acoustically transparent below to parallel reflectors above. However, reflector R2 (Duin and Kok, 1984; Rothwell et al., Chap. 28, this volume), has been taken to mark the boundary between seismic Units A2 and A3. This is a prominent reflector that lies above the change in turbidite accumulation rates at the position of a particularly thick gray nonvolcanic turbidite.

Rothwell, et al. (Chap. 28, this volume), also identified seismic reflectors R1 and R0 within this interval of turbidites. We do not see any distinctive turbidites at the position of reflector $\mathrm{R} 1(\sim 3.5 \mathrm{Ma})$, but reflector R0 coincides with a thick gray nonvolcanic turbidite at 1.6 Ma.

\section{SEDIMENT BUDGETS}

The seismic reflectors R0 to R4 were traced across the whole abyssal plain by Rothwell et al. (Chap. 28, this volume), and the volumes of sediment calculated for each seismic unit between adjacent reflectors. Because the relative proportion of each turbidite type is similar at each of the widely spaced sites, we have assumed that the averages of these proportions are representative of the whole basin.
We thus have used these proportions to calculate the total volume of each turbidite type deposited in each seismic unit. Results are presented in Table 1 and shown in Figure 8, plotted in three separate ways. The first graph shows the volume of each turbidite type in each seismic unit without any correction for compaction. Sediments become more compacted with depth of burial, but the original sediment that was eroded to form the turbidity current came from the surficial few tens of meters of the sediment column in the source areas (see Weaver, 1994). The second graph takes the compaction effect into account by using decompacted volumes for the basin infill (values from Rothwell et al., Chap. 28, this volume). This has the effect of increasing the volumes, particularly in the deeper seismic units. The third set of data takes into account the duration of each seismic unit and the decompaction effect to determine the volume of sediment derived from each source per million years for each seismic unit. These data sets account for $80 \%-90 \%$ of the total volume of sediment in each seismic unit; the rest comprise pelagic units and missing core. The data show the organic source to have been dominant throughout, contributing nearly $10,000 \mathrm{~km}^{3}$ of sediment in the last $16 \mathrm{~m}$.y. The deepest drilling at Sites 951 and 952 suggests the northwest African margin was also the principal source prior to this time. The volume of organic turbidites more than doubled between seismic Units A3 and A2 ( 6 Ma), and the highest input of these flows was in seismic Unit A1 (3.5-1.6 Ma).

A total of nearly $3000 \mathrm{~km}^{3}$ of sediment was derived from the Canary Islands in the last 16 m.y. This source shows a steadily increasing input with time. This may be because of increasing volcanic activity in the chain as shown by the addition of new islands; Gran Canaria ( 15 Ma), Tenerife ( $7 \mathrm{Ma})$, La Palma $(<3 \mathrm{Ma})$, and Hierro $(<1$ $\mathrm{Ma}$ ), with the older islands remaining active throughout. The contribution of gray nonvolcanic flows is interesting in this aspect because they pulse into the plain at the times when new islands were forming, namely 15-17 Ma, 7-7.5 Ma, 5.5-6 Ma, and 1.5-1.6 Ma. These flows form some of the largest units encountered (e.g., a single turbidite of $11 \mathrm{~m}$ thickness between 189 and $200 \mathrm{mbsf}$ in Site 951). They have the same color as the volcanic turbidites, but have very low magnetic susceptibilities, suggesting a low volcanic component. They do not contain significant proportions of organic material and thus cannot be generated in the upwelling cells off northwest Africa. It is possible that these turbidity currents were initiated as slope failures during the early subaerial development of the volcanic islands, when their flanks were composed largely of pelagic sediment without much volcanic debris.

The calcareous turbidites do not show major changes with time, but the volumes contributed to seismic Unit A3 are almost entirely caused by the deposition of three calcarenites between 17 and 16 m.y. From 6 Ma to the present, the contribution of $130-175 \mathrm{~km}^{3} / \mathrm{m}$.y. reflects a balance between production and erosion on the seamount flanks. Brown turbidites are of only minor significance in the deeper Units A2 and A3 and are presumably a subgroup of the calcareous turbidites, produced from the western seamounts when CCD levels were much shallower.

\section{PORE-WATER GEOCHEMISTRY Organic Matter Driven Reactions}

Shipboard data (Schmincke, Weaver, Firth, et al., 1995) demonstrate that bacterially mediated oxidation of organic matter exerts a major control on MAP pore-water geochemistry, despite the deepwater $(5.4 \mathrm{~km})$ setting and low pelagic sedimentation rates $(0.5-5 \mathrm{~m} /$ m.y.; Howe and Sblendorio-Levy, Chap. 29, this volume). Labile organic matter is essentially confined to green organic-rich turbidites that have been derived from high productivity areas off the northwest African continental margin. Oxic conditions (indicated by the pres- 

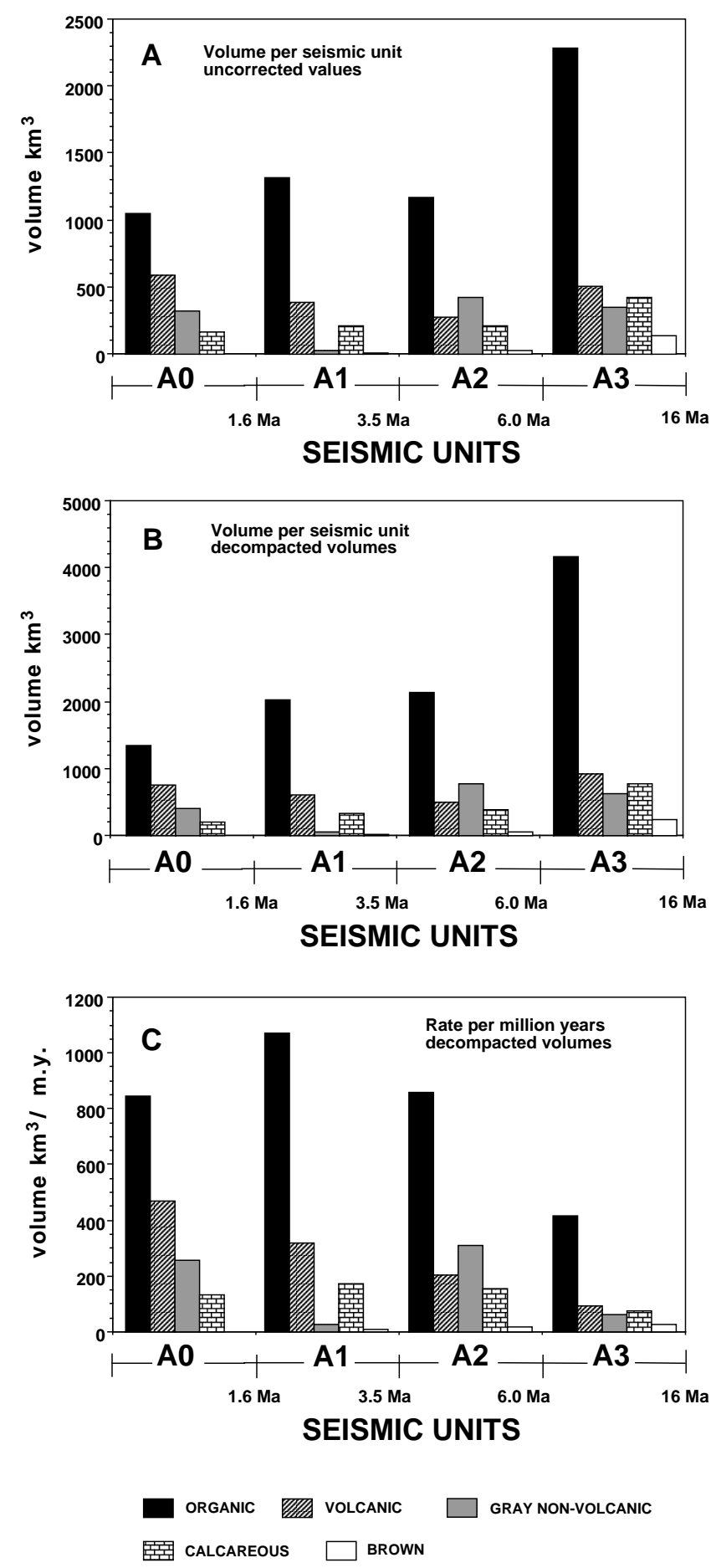

Figure 8. Sediment budgets for the MAP turbidite sequence. A. Total volume of each turbidite type in each seismic unit. B. Total volume of each turbidite type taking into account compaction. Values are decompacted to resemble the surface sediments which were eroded to form the flows. C. Rate of accumulation of each turbidite type in each seismic unit. ence of pore-water $\mathrm{O}_{2}$ and $\mathrm{NO}_{3}^{-}$) persist only to $20-30 \mathrm{~cm}$ below the seafloor on the MAP (Wilson et al., 1985, 1986; Thomson et al., 1987, 1989), below which the coexistence of $\mathrm{Mn}^{2+}, \mathrm{Fe}^{2+}$ and $\mathrm{NH}_{4}{ }^{+}$ demonstrate that suboxic conditions prevail.

At all three MAP sites, convex-up interstitial sulfate profiles (Fig. 9) and an inverse relationship between sulfate and ammonia demonstrate that bacterial sulfate reduction must be occurring in sediments below 130 mbsf. The stoichiometry of this process (Emerson et al., 1980) may be approximated by

$$
\begin{gathered}
\left(\mathrm{CH}_{2} \mathrm{O}\right)_{106}\left(\mathrm{NH}_{3}\right)_{16} \mathrm{H}_{3} \mathrm{PO}_{4}+53 \mathrm{SO}_{4}{ }^{2-} \Rightarrow \\
67 \mathrm{HCO}_{3}^{-}+39 \mathrm{CO}_{2}+16 \mathrm{NH}_{4}^{+}+53 \mathrm{HS}^{-}+\mathrm{HPO}_{4}{ }^{2-}+39 \mathrm{H}_{2} \mathrm{O}
\end{gathered}
$$

However, despite broad similarities between pore-water profiles, subtle differences exist between sites on the MAP. At Site 950, $\mathrm{SO}_{4}{ }^{2-}$ declines to a minimum between 150 and 270 mbsf (Fig. 9), before increasing again toward the base of the hole, whereas $\mathrm{NH}_{4}{ }^{+}$reaches a maximum $\sim 130 \mathrm{mbsf}$ and then declines downward. The upper parts of these profiles are consistent with modest rates of sulfate reduction, with the lower parts demonstrating removal of $\mathrm{NH}_{4}{ }^{+}$, and a possible supply of $\mathrm{SO}_{4}{ }^{2-}$. The former may be attributed to ammonia uptake by clays (Müller, 1977; Gieskes, 1983), as indicated by a downhole trend of rising nitrogen contents and decreasing $\mathrm{C}: \mathrm{N}$ ratios in the formerly oxic, $\mathrm{C}_{\text {org }}$ lean tops of organic-rich turbidites (Cowie et al., Chap. 34, this volume). Organic-rich turbidites are absent below 300 mbsf, and the lower section is dominated by pelagic red clays and volcaniclastic sandstones. Alteration processes in these deeper sediments could provide further absorption of $\mathrm{NH}_{4}{ }^{+}$by smectites and liberation of $\mathrm{SO}_{4}{ }^{2-}$ from volcanic glasses (Schmincke, Weaver, Firth, et al., 1995). On the other hand, greatly increased sedimentation rates from $8 \mathrm{~m} / \mathrm{m}$.y. at $300 \mathrm{mbsf}$ to $39 \mathrm{~m} / \mathrm{m}$.y. in the upper sediment section (Howe and Sblendorio-Levy, Chap. 29, this volume) would have incorporated increased proportions of labile organic matter, causing higher rates of sulfate reduction in the upper part of the sequence.

Methane is present at Sites 950 at low concentrations of a few $\mu \mathrm{g} /$ $\mathrm{mL}$ above 300 mbsf (Fig. 9), reaching a broad maximum $\sim 130 \mathrm{mbsf}$. Methanogenesis in shallow-buried sediments is also a bacterially driven process (Froelich et al., 1979) that proceeds by decomposition of organic matter according to the reaction

$$
\begin{gathered}
\left(\mathrm{CH}_{2} \mathrm{O}\right)_{106}\left(\mathrm{NH}_{3}\right)_{16} \mathrm{H}_{3} \mathrm{PO}_{4} \Rightarrow 53 \mathrm{CH}_{4}{ }^{+}+53 \mathrm{CO}_{2} \\
+16 \mathrm{NH}_{3}+5 \mathrm{H}_{3} \mathrm{PO}_{4} .
\end{gathered}
$$

However, significant quantities of methane generally develop only in sediments after sulfate has been exhausted (e.g., Cragg et al., 1996), because sulfate reducing bacteria out-compete methanogenic groups, and because microbially mediated methane oxidation prevents a build-up of $\mathrm{CH}_{4}$ :

$$
\mathrm{SO}_{4}{ }^{2-}+\mathrm{CH}_{4} \Rightarrow \mathrm{HS}^{-}+\mathrm{HCO}_{3}^{-}+\mathrm{H}_{2} \mathrm{O} \text {. }
$$

At Site 950, the methane and ammonia maxima coincide but lie above the sulfate minimum, so methanogenesis may contribute to the $\mathrm{NH}_{4}{ }^{+}$flux. Thicker sequences of organic-rich turbidites were recovered at Sites 951 and 952. At the former, increased depletion of porewater sulfate and production of ammonia is evident (Fig. 9), indicating higher rates of sulfate reduction. In this case, the sulfate minimum and ammonia maximum occur $200 \mathrm{mbsf}$, and ammonia concentrations are only marginally depleted at the base of the hole, indicating reduced clay mineral diagenesis within the sampled section. The highest rates of sulfate reduction are evident at the most easterly site, 952, with near-complete removal of $\mathrm{SO}_{4}^{2-}$, a strong negative correlation between pore-water $\mathrm{SO}_{4}{ }^{2-}$ and $\mathrm{NH}_{4}{ }^{+}$, and high concentrations of 

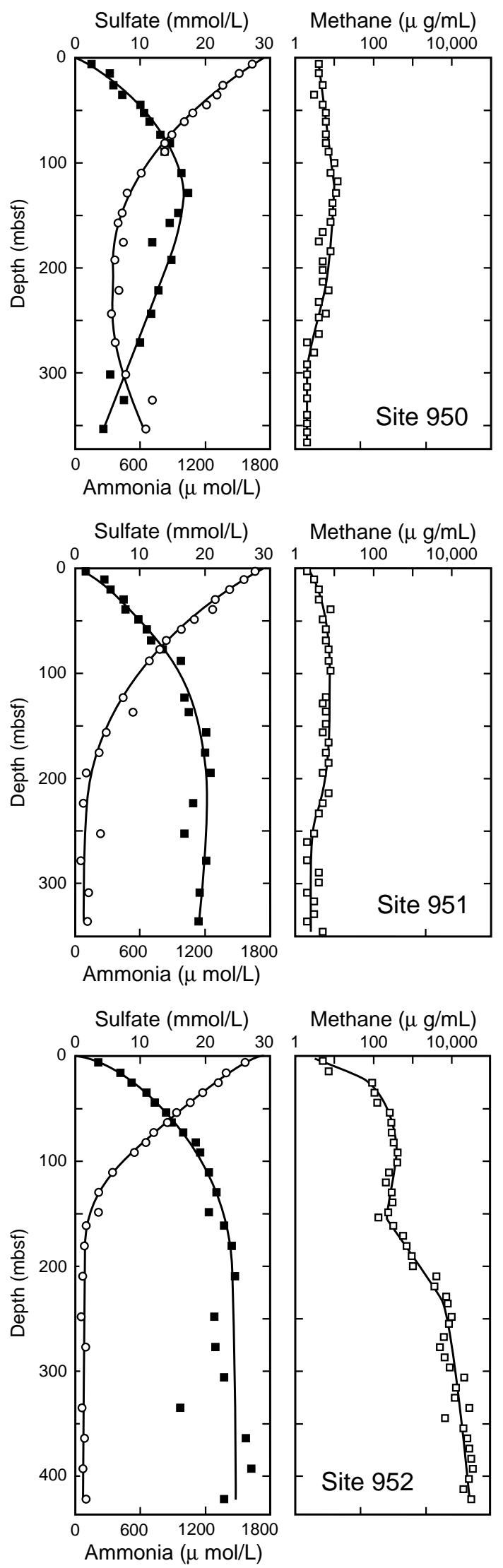

Figure 9. Pore-water geochemical profiles for sulfate (open circles), ammonia (solid squares), and methane (open squares) at Sites 950, 951, and 952. Data from Schmincke, Weaver, Firth, et al. (1995).
$\mathrm{CH}_{4}$ below 150 mbsf. A stepped $\mathrm{CH}_{4}$ profile (Fig. 9) and a flattened $\mathrm{SO}_{4}{ }^{2-}$ curve suggest that methane oxidation is occurring $\sim 150 \mathrm{mbsf}$, but the strong relationship between $\mathrm{SO}_{4}{ }^{2-}$ and $\mathrm{NH}_{4}{ }^{+}$demonstrate that methane oxidation (cf. Borowski et al., 1996) cannot alone be responsible for declining $\mathrm{SO}_{4}{ }^{2-}$. The high methane flux may be attributed to a thick sequence of organic-rich turbidites occurring below the cored interval and perhaps to increased proportions of labile organic matter in turbidites from this more proximal site.

Pore-water alkalinity, calcium, and magnesium trends (Schmincke, Weaver, Firth, et al., 1995) at all three MAP sites, indicate that calcite is precipitating $\sim 100 \mathrm{mbsf}$ in response to rising alkalinities caused by the post-oxic decomposition of organic matter, whereas rising $\mathrm{Ca}^{2+}$ and falling $\mathrm{Mg}$ :Ca ratios at intermediate depths suggest precipitation of dolomite in the sulfate-reducing zone. Falling $\mathrm{Mg}^{2+}$ associated with rapidly rising $\mathrm{Ca}^{2+}$ in the lower parts of each hole probably accompany the precipitation of diagenetic clay minerals associated with the breakdown of volcanic glass.

\section{Silica Diagenesis}

Unlike most other pore-water species, silica profiles are irregular and display a remarkable degree of similarity between the three MAP sites (Schmincke, Weaver, Firth, et al., 1995; De Lange, Chap. 36, this volume). Dissolution of biogenic silica within individual organic-rich turbidites probably provides the main control on pore-water silica concentrations. Silica pore-water concentrations in the Pleistocene (Fig. 10) faithfully record the presence of biogenic silica (diatom, silica sponge, and rare radiolarian debris) in specific organicrich turbidites, which are also distinguished by high solid-phase $\mathrm{Si}$ / $\mathrm{Al}$ ratios. For example, at Site 950, pore-water silica concentrations up to $650 \mu \mathrm{mol} / \mathrm{L}$ occur in a package of organic-rich turbidites between 30 and $35 \mathrm{mbsf}$ that have $\mathrm{Si} / \mathrm{Al}$ ratios up to 3.5. The highly irregular pore-water profiles necessitate that the supply of silica to pore-waters is matched by precipitation of a silica-bearing diagenetic phase, otherwise profiles would become smoothed by diffusion, and silica concentrations would rise close to their solubility limit of 1,000 $\mu \mathrm{mol} / \mathrm{L}$ (Hurd, 1973). Diagenetic minerals such as smectites, chamosite or nontronite provide potential sinks for silica, although their presence at the appropriate levels has yet to be confirmed.

Through the upper Miocene to upper Pliocene, silica pore-water concentrations and $\mathrm{Si} / \mathrm{Al}$ ratios are low and fall progressively downward (Fig. 10), indicating an absence of preserved biogenic silica in this interval. High $\mathrm{Si} / \mathrm{Al}$ ratios for four samples from Site 950 (at 110, 166, and 198 mbsf; Fig. 10) taken from the lower portions of turbidites are explained by the presence of detrital quartz in graded basal silts. Rising silica pore-water concentrations below $270 \mathrm{mbsf}$ in the middle Miocene are matched by increasing $\mathrm{Si} / \mathrm{Al}$ ratios, both of which suggest the reappearance of biogenic opal-bearing sediments. The absence of this relationship in the overlying sediments indicates that organic-rich turbidites deposited during the late Miocene to late Pliocene contained little $(<1 \%)$ or no biogenic silica, implying a reduced nutrient supply in their source area and/or a different provenance for these beds.

\section{Geochemical Processes at Fossil Redox Fronts Inorganic Geochemistry}

Efficient mixing by turbidity currents and removal of the coarse fraction in proximal areas ensure that MAP distal mud turbidites are remarkably homogenous when deposited. This makes them uniquely suited to studies of inorganic and organic diagenetic processes in sediments, because many of the complex interactions present in other sedimentary systems are absent, including variations in sediment sources, productivity, organic matter composition, sedimentation rates, reworking, and bioturbation. 


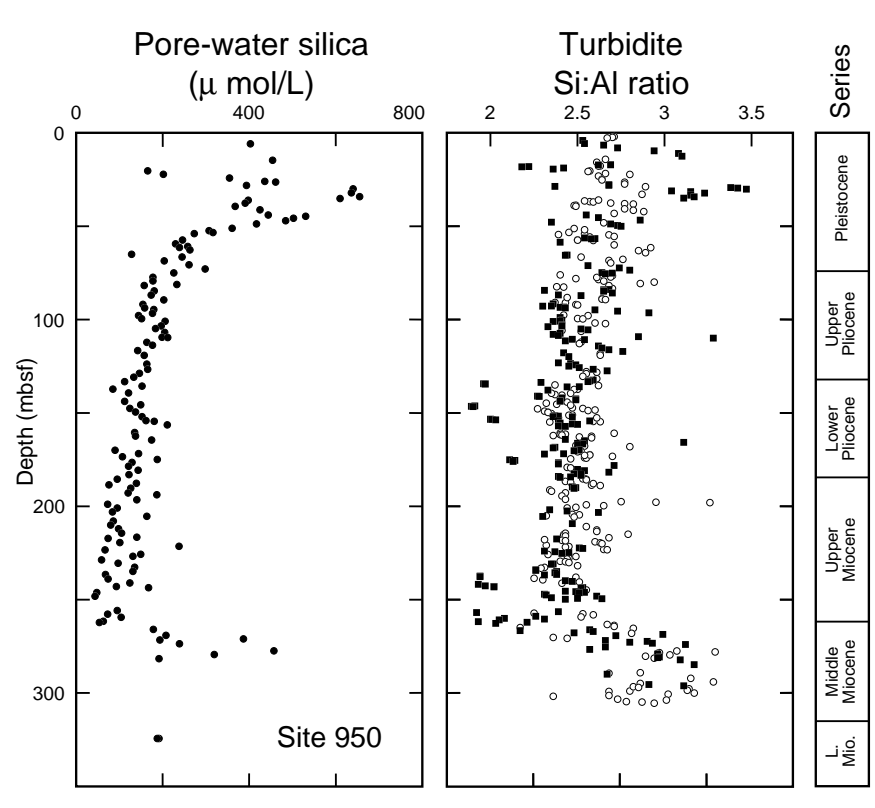

Figure 10. Pore-water silica and turbidite $\mathrm{Si} / \mathrm{Al}$ ratios, Site 950 . Solid circles = pore-water data (all lithologies after De Lange, Chap. 36, this volume), solid squares $=$ solid-phase data from organic-rich turbidites, and open circles $=$ other categories (after Jarvis et al., Chap. 31, this volume).

Following deposition, organic-rich turbidites are immediately oxidized by seawater oxygen, diffusing downward from the sediment/ water interface. This process progressively destroys labile organic matter at the summit of the turbidite, causing the development of a two-tone color, with green sediments below, overlain sharply by paler, gray, or brown muds. The color change marks a sharp redox boundary (Wilson et al., 1985, 1986) with pore-water $\mathrm{O}_{2}$ and $\mathrm{NO}_{3}^{-}$ both completely consumed above, and $\mathrm{Mn}^{2+}, \mathrm{Fe}^{2+}$, and $\mathrm{NH}_{4}^{+}$all present in solution immediately below.

Oxidation continues for as long as each turbidite is in diffusive contact with bottom waters, causing the progressive burn-down of the redox boundary. The duration of this process is generally a few tens of thousands of years on the MAP (Buckley and Cranston, 1988; Weaver et al., 1992), where turbidite emplacement occurs at frequent intervals, and consequently affects only the uppermost few decimeters of sediment in beds which are typically several meters thick. The development of such a sharp redox interface causes the early diagenetic redistribution of redox-sensitive elements around the color change (Colley and Thomson, 1985, 1990, 1992; Jarvis and Higgs, 1987; Kennedy and Elderfield, 1987; Buckley and Cranston, 1988; Colley et al., 1984, 1989; Cranston and Buckley, 1990; Colodner et al., 1992; van Os et al., 1993; Rosenthal et al., 1995).

The sequence of element redistribution peaks around oxidation fronts in Quaternary turbidites is remarkably similar to that observed in an upper Miocene organic-rich turbidite at Site 950 (Thomson et al., Chap. 32, this volume), and now buried to $230 \mathrm{mbsf}$. This unit was deposited $\sim 7.6 \mathrm{Ma}$, and must have consecutively experienced $\sim 3.8$ m.y. each of post-oxic and sulfate-reducing conditions. However, unlike younger examples, carbonate has been entirely removed by dissolution from the formerly oxic top of this turbidite. Dissolution may be explained partly by the generation of $\mathrm{CO}_{2}$ that accompanied oxygen and nitrate reduction:

$$
\begin{gathered}
138 \mathrm{O}_{2}+\left(\mathrm{CH}_{2} \mathrm{O}\right)_{106}\left(\mathrm{NH}_{3}\right)_{16} \mathrm{H}_{3} \mathrm{PO}_{4}+18 \mathrm{HCO}_{3}{ }^{-} \Rightarrow \\
124 \mathrm{CO}_{2}+16 \mathrm{NO}_{3}{ }^{-}+\mathrm{HPO}_{4}{ }^{2-}+140 \mathrm{H}_{2} \mathrm{O}
\end{gathered}
$$

$$
\begin{gathered}
\text { 94.4 } \mathrm{NO}_{3}^{-}+\left(\mathrm{CH}_{2} \mathrm{O}\right)_{106}\left(\mathrm{NH}_{3}\right)_{16} \mathrm{H}_{3} \mathrm{PO}_{4}+18 \mathrm{HCO}_{3}^{-} \Rightarrow \\
13.6 \mathrm{CO}_{2}+92.4 \mathrm{HCO}_{3}{ }^{-}+55.2 \mathrm{~N}_{2}+84.8 \mathrm{H}_{2} \mathrm{O}+\mathrm{HPO}_{4}{ }^{2-} \\
\mathrm{CO}_{2}+\mathrm{H}_{2} \mathrm{O}+\mathrm{CaCO}_{3} \Leftrightarrow \mathrm{Ca}^{2+}+2 \mathrm{HCO}_{3}^{-} .
\end{gathered}
$$

Oxidation of organic sulfur compounds and sulfides would also contribute to carbonate dissolution. However, the total effect of oxidation of organic matter and reduced sulfur on carbonate dissolution is equivalent to $\sim 1 \% \mathrm{CaCO}_{3}$ per $0.2 \% \mathrm{C}_{\text {org }}$ (De Lange, Chap. 33, this volume). The $\mathrm{C}_{\text {org }}$ content of the unoxidized portion of the upper Miocene turbidite is $\sim 1.4 \%$ (Thomson et al., Chap. 32, this volume), so the amount of carbonate dissolved $(\sim 25 \%)$ considerably exceeds that predicted. Dissolution by carbonate-undersaturated bottom waters may have been responsible for the removal of additional $\mathrm{CaCO}_{3}$ (Cranston and Buckley, 1990), because excess carbonate dissolution is seen in most turbidites deposited before $2.7 \mathrm{Ma}$ (De Lange, Chap. 33 , this volume), when the calcite compensation depth (CCD) was considerably shallower (Lebreiro et al., Chap. 30, this volume).

The organic carbon $\left(\mathrm{C}_{\text {org }}\right)$ profile and $\mathrm{C}_{\text {org }}$ :S ratio of the upper Miocene turbidite are comparable to those in younger examples (Thomson et al., Chap. 32, this volume), so despite the fact that pore-water data (Fig. 10) indicate that $C_{\text {org }}$ remineralization is continuing in the buried section, no evidence for significant new sulfide formation is provided by $\mathrm{C}_{\text {org }} / \mathrm{S}$ ratios. On the other hand, there is evidence that $\mathrm{Fe}$ and $\mathrm{Mn}$, expected to have been precipitated as oxyhydroxides in oxic conditions at the active front, are still present in excess quantities in the formerly oxic zone. Controls on these excess quantities are likely to be sorption on $\mathrm{CaCO}_{3}$ for $\mathrm{Mn}$ as $\mathrm{Mn}$ (II), and Fe silicate rather than Fe sulfide formation.

The labile (nondetrital) fractions of many redox-sensitive elements remain concentrated around the sharp color change from dark green (below) to greenish gray (above) in the upper Miocene turbidite. For example, $\mathrm{Cd}, \mathrm{Sb}, \mathrm{Se}, \mathrm{Tl}$, and V are all still found in peaks immediately below the original oxic/post-oxic boundary although, as in the younger turbidites, the peaks are not exactly coincident. This is believed to be a consequence of their individual responses to the redox gradient developed on the oxic/post-oxic boundary of the progressive oxidation front. By contrast, a proportion of $\mathrm{Co}, \mathrm{Cu}, \mathrm{Ni}$, and $\mathrm{Zn}$, which were also originally fixed below the active redox interface, has apparently moved upward in chromatographic-like fronts, probably as sulfide complexes, which are seen as thin dark purple or gray bands in the core. Similar bands have been observed in Quaternary fossil (but not active) oxidation fronts (Jarvis and Higgs, 1987; van Os et al., 1993).

Arsenic and $\mathrm{U}$ have stepped concentration profiles (Thomson et al., Chap. 32, this volume), owing to their removal from sediment above the color change by the bacterially driven redox processes that accompanied oxic decomposition of $\mathrm{C}_{\text {org }}$; there is no evidence of later remobilization of these elements. Sulfur shows stepped profiles in all of the organic-rich turbidites studied (Thomson et al., Chap. 32; De Lange, Chap. 33, both this volume), but the sulfur increase is offset slightly below that of $\mathrm{C}_{\text {org }}$, indicating that sulfide oxidation slightly preceded that of organic matter. The origin of relatively high $S$ contents observed in sediments above some relic redox fronts remains uncertain, but is partly because of pore-water sulfate and some barite. Overall, it is remarkable that the successive passage of MAP turbidites through several millions of years of post-oxic then sulfatereducing conditions has had so little effect on trace-metal distributions.

\section{Organic Geochemistry}

The primary homogeneity of MAP turbidites makes them ideally suited to the study of long-term oxidation processes in marine sediments, making it possible to assess the extent and possible selectivity 
of oxic vs. anoxic degradation of $\mathrm{C}_{\text {org. }}$. Kerogen represents $>90 \%$ of the organic matter present and, within individual turbidites, is initially homogeneous, even at the molecular level.

The organic geochemistry of samples taken from above and below relic redox fronts has been studied (Cowie et al., Chap. 34; De Lange, Chap. 33; Hoefs et al., Chap. 35; all this volume) in selected organic-rich Pleistocene to middle Miocene turbidites at Sites 951 and 952. Results are consistent with previous work on Quaternary sediments (Prahl et al., 1989, 1997; De Lange et al., 1994; Cowie et al., 1995), with large decreases of organic carbon $(\sim 80 \%)$ and total nitrogen contents $(\sim 50 \%)$ in formerly oxic turbidites tops, and an associated drop in sediment $\mathrm{C} / \mathrm{N}$ ratios from $\sim 12$ below, to $4-5$ above the relic redox interfaces. Most of the nitrogen in MAP turbidites resides in organic matter (De Lange, Chap. 33, this volume), so lower $\mathrm{C} / \mathrm{N}$ ratios cannot be attributed to a large sediment-bound nitrogen reservoir, but could be ascribed to ammonia fixation by clays (see above). The $\mathrm{C} / \mathrm{N}$ ratio of the organic matter which has been decomposed is $\sim 15$, close to that found in many open marine sediments, but higher than that in plankton (6.6).

Samples taken from below relic redox fronts consistently yield $\delta^{13} \mathrm{C}_{\text {org }}$ of $-20 \%$ o to $-21 \%$ and $\delta^{15} \mathrm{~N} \sim+5 \%$, values that are typical of oceanic sediments dominated by marine organic matter. Oxic decomposition processes have resulted in $\delta^{13} \mathrm{C}_{\text {org }}$ that is on average $1.5 \%$ lighter, and $\delta^{15} \mathrm{~N}$, which is $1.7 \%$ o heavier, whereas post-oxic and anoxic diagenesis appear to have had little effect on the stable-isotope geochemistry. This trend to lighter carbon isotopic signatures could be attributed to the selective oxidation of marine relative to terrestrial organic matter (Prahl et al., 1997), but this appears to be inconsistent with falling $\mathrm{C} / \mathrm{N}$ ratios and the complete removal of pollen (Keil et al., 1994a). Preferential remineralization of ${ }^{14} \mathrm{~N}$ under oxic conditions typically promotes a shift to heavier isotopic signatures (Altabet and Francois, 1994). This trend to heavy values following oxidation also appears to be inconsistent with the preferential preservation of (isotopically light) terrestrial material, but nitrogen uptake by clays provides a potential mechanism for isotopic fractionation which is currently uncharacterized. On the other hand, low lignin yields, low initial C/N ratios, and biochemical data (Cowie et al., 1995; Hoefs et al., Chap. 35, this volume) indicate that the organic matter is mostly marine. Lignin losses across the relic redox fronts parallel those of organic carbon (Cowie et al., Chap. 34, this volume), suggesting that oxidation is nonselective with respect to terrestrial material, and oxidation also promotes no change in the value of a number of organic geochemical paleotemperature indicators (Prahl et al., 1989; De Lange et al., 1994; Cowie et al., 1995). By contrast, changes in kerogen composition (Hoefs et al., Chap. 35, this volume) indicate that oxic degradation of marine organic matter can itself be selective, and once again, effects caused by the early postdepositional oxidation of organic matter by oxygen are far more severe than those attributable to later electron acceptors. Clearly, great care is needed in interpreting the origin and history of organic matter in even relatively simple diagenetic regimes.

Sorption of organic material onto mineral surfaces is an important control on the amount and quality of $\mathrm{C}_{\text {org }}$ that accumulates in marine sediments (Mayer 1994; Keil et al., 1994b). Sorption appears to protect otherwise labile organic material by rendering it inaccessible to bacteria or their enzymes, and a remarkably constant relationship is found between mineral surface area and organic matter content in a wide range of continental margin sediments. Mineral surface area in MAP organic-rich turbidites (Cowie et al., Chap. 34, this volume) is inversely related to $\mathrm{CaCO}_{3}$ content, reflecting the more equant morphology and larger size of carbonate grains compared to clay minerals. Organic matter loadings in the lower portions of turbidites are close to those predicted $\left(0.5-1 \mathrm{mg} \mathrm{C} \mathrm{org}_{\mathrm{o}} / \mathrm{m}^{2}\right)$ from measured surface areas, but oxic decomposition above relic redox fronts has caused organic matter loadings to fall dramatically, owing to dissolution of both carbonate and organic matter.
Overall, organic geochemical data indicate that oxygen availability provides the overriding control on organic matter content and composition in these pelagic environments, and that post-oxic and anoxic diagenesis may have remarkably little effect on bulk compositions over periods of up to $13 \mathrm{~m} . \mathrm{y}$. These observations provide strong support for those arguing (e.g., Demaison and Moore, 1980; Pratt, 1984; Canfield, 1989, 1993) for the importance of oxygen in controlling organic matter preservation in the oceans.

\section{CONCLUSIONS}

Drilling the Madeira Abyssal Plain has given great insight into the way in which deep-sea basins develop through time. The MAP began to receive turbidity currents from the early Miocene, although the first flows were relatively low volume and mostly from the northwest African margin. These filled the fracture zone valleys. By $16 \mathrm{Ma}$, these valleys were almost full and some large flows from seamounts to the west spread across the whole plain. Between 16 and $13 \mathrm{Ma}$, the organic flows from the northwest African margin also became larger and began to spread across the plain. Turbidity currents from the Canary Islands also entered the plain, but in relatively low volumes. At $7 \mathrm{Ma}$, there was a large increase in the number and volume of volcanic flows, and this was followed at $6.5 \mathrm{Ma}$ by an increase in the number and volume of organic flows from northwest Africa as well as calcareous flows from the western seamounts. These higher rates have continued to the present day.

The changes in erosion rates within the basin may be related to global paleoceanographic changes. The middle Miocene saw a buildup of ice on Antarctica that would have lowered sea levels and thus reduced the width of the continental shelves. This, in turn, led to less sediment trapping on the shelves and to potentially higher accumulation rates on the shelf edge/upper slope, which may have become unstable. Alternatively, circulation changes may have caused an increase in the amount of upwelling off northwest Africa, again causing higher accumulation rates on the shelf edge/upper slope. The changes at $6.5 \mathrm{Ma}$ are also related to increased ice growth on Antarctica (Muller et al., 1991) and the start of the Messinian salinity crisis.

The different sources of turbidites have given each a distinct geochemical signature and thus a chemostratigraphic scheme has been produced that complements the conventional lithostratigraphy. Compositional variation within individual groups demonstrate the evolution of, and shifts between, different source areas. Stratigraphic variation in the composition of organic turbidites suggests an increasing importance of more northerly derived sediments from the northwest African margin since the middle Miocene. Peaks in porewater silica profiles reflect enhanced biogenic silica in Pleistocene and middle Miocene organic turbidites. The pulsed emplacement history and changing geochemical composition of volcanic turbidites is attributed to the progressive addition of new islands to the Canary chain, and their subsequent geochemical fractionation.

The MAP has proved to be an ideal natural laboratory in which the effects of early sediment diagenesis can be traced over tens of millions of years by examining turbidites with similar compositions deposited through the sequence. Diagenesis of MAP MioceneHolocene sediments is dominated by oxic processes that occurred when organic-rich turbidites were first emplaced on the plain. Diffusion of seawater oxygen into the upper few decimeters of turbidite tops and over time periods of a few thousand years caused the nearcomplete destruction of labile organic matter in the sediment. Oxidation has resulted in lower $\mathrm{CaCO}_{3}$ and $\mathrm{C}_{\text {org }}$ contents, lower $\mathrm{C} / \mathrm{N}$ ratios, lighter ${ }^{13} \mathrm{C}_{\text {org }}$ and heavier ${ }^{15} \mathrm{~N}$ in turbidite tops, and has promoted the early diagenetic migration of trace metals (particularly $\mathrm{Cd}, \mathrm{Co}, \mathrm{Cu}$, $\mathrm{Ni}, \mathrm{Sb}, \mathrm{Se}, \mathrm{Tl}, \mathrm{V}$, and $\mathrm{Zn}$ ) around a sharply defined redox interface. Pore-water data demonstrate that subsequent burial to depths of $>350$ mbsf, and for time periods in excess of 10 m.y., has led to the pro- 
gressive development of post-oxic $(<1 \mathrm{mbsf})$ and sulfate-reducing (>130 mbsf) conditions, but these have had remarkably little effect on bulk sediment compositions, trace-metal distributions, or organic matter geochemistry. Oxygen availability at the seafloor appears to be an overriding control on diagenetic processes and rates in these pelagic environments.

\section{ACKNOWLEDGMENTS}

P.P.E. Weaver, S.M. Lebreiro, B. Alibes, and R. Howe gratefully acknowledge support from the European Commission on Marine Science and Technology (MAST II) program (Sediment Transport on European Atlantic Margins [STEAM]) grant MAS2-CT94-0083). Weaver, Lebreiro, and R.G. Rothwell also acknowledge support from NERC grant No. GST/02/0990. I. Jarvis was supported by NERC grant No. GST/02/1097.

\section{REFERENCES}

Altabet, M.A., and Francois, R., 1994. Sedimentary nitrogen isotopic ratio as a record for surface ocean nitrate utilization. Global Biogeochem. Cycles, 8:103-116.

Borowski, W.S., Paull, C.K., and Ussler, W., III, 1996. Marine pore-water sulfate profiles indicate in situ methane flux from underlying gas hydrate. Geology, 24:655-658.

Buckley, D.E., and Cranston, R.E., 1988. Early diagenesis in deep sea turbidites: the imprint of paleo-oxidation zones. Geochim. Cosmochim. Acta, 52:2925-2939.

Canfield, D.E., 1989. Sulfate reduction and oxic respiration in marine sediments: implications for organic carbon preservation in euxinic environments. Deep-Sea Res. Part A, 36:121-138.

1993. Organic matter oxidation in marine sediments. In Wollast, R., Chou, L., and Mackenzie, F. (Eds.), Interactions of C, N, P, and S Biogeochemical Cycles. NATO Adv. Res. Workshop, Berlin, 333-363.

Colley, S., and Thomson, J., 1985. Recurrent uranium relocations in distal turbidites emplaced in pelagic conditions. Geochim. Cosmochim. Acta, 49:2339-2348.

, 1990. Limited diffusion of U-series radionuclides at depth in deep-sea sediments. Nature, 346:260-263.

, 1992. Behavior and mobility of U-series radionuclides in Madeira Abyssal Plain turbidites over the past 750,000 years. Mar. Geol., 109:141-158.

Colley, S., Thomson, J., and Toole, J., 1989. Uranium relocations and derivation of quasi-isochrons for a turbidite/pelagic sequence in the Northeast Atlantic. Geochim. Cosmochim. Acta, 53:1223-1234.

Colley, S., Thomson, J., Wilson, T.R.S., and Higgs, N.C., 1984. Post-depositional migration of elements during diagenesis in brown clay and turbidite sequences in the North East Atlantic. Geochim. Cosmochim. Acta, 48:1223-1235.

Colodner, D.C., Boyle, E.A., Edmond, J., and Thomson, J., 1992. Post-depositional mobility of platinum, iridium and rhenium in marine sediments. Nature, 358:402-404.

Cowie, G.L., Hedges, J.I., Prahl, F.G., and de Lange, G.J., 1995. Elemental and major biochemical changes across an oxidation front in a relict turbidite: an oxygen effect. Geochim. Cosmochim. Acta, 59:33-46.

Cragg, B.A., Parkes, R.J., Fry, J.C., Weightman, A.J., Rochelle, P.A., and Maxwell, J.R., 1996. Bacterial populations and processes in sediments containing gas hydrates (ODP Leg 146: Cascadia Margin). Earth Planet. Sci. Lett., 139:497-507.

Cranston, R.E., and Buckley, D.E., 1990. Redox reactions and carbonate preservation in deep-sea sediments. Mar. Geol., 94:1-8.

Davies, T.L, van Neil, B., Kidd, R.B., and Weaver, P.P.E., 1997. Erosional characteristics and turbidity current links between the Seine and Madeira Abyssal Plain turbidites calculated from reworked coccolith assemblages. Geo-Mar. Lett., 17:147-153.

De Lange, G.J., Jarvis, I., and Kuijpers, A., 1987. Geochemical characteristics and provenance of late Quaternary sediments from the Madeira Abyssal Plain, North Atlantic. In Weaver, P.P.E., and Thomson, J. (Eds.), Geology and Geochemistry of Abyssal Plains. Geol. Soc. Spec. Publ. London, 31:147-165.
De Lange, G.J., Middelburg, J.J., Jarvis, I., and Kuijpers, A., 1989. Geochemical characteristics and provenance of late Quaternary sediments from the Madeira and southern Nares Abyssal Plains (North Atlantic). In Schuttenhelm, R.T.E., Auffret, G.A., Buckley, D.E., Cranston, R.E., Murray, C.N., Shephard, L.E., and Spijkstra, A.E. (Eds.), Geoscience Investigations of Two North Atlantic Abysal Plain-The ESOPE International Expedition: Luxembourg (Commission of the European Community), 2:785-851.

De Lange, G.J., van Os, B., Pruysers, P.A., Middelburg, J.J., Castradori, D., van Santvoort, P., Müller, P.J., Eggenkamp, H., and Prahl, F.G., 1994. Possible early diagenetic alteration of palaeo proxies. In Zahn, R., Pedersen, T.F., Kaminski, M.A., and Laneyrie, L. (Eds.), Carbon Cycling in the Glacial Ocean: Constraints on the Ocean's Role in Global Change. NATO ASI Ser., I17:225-258.

Demaison, G.J., and Moore, G.T., 1980. Anoxic environments and oil source bed genesis. AAPG Bull., 64:1179-1209.

Duin, E.J.T., and Kok, P.T.J., 1984. A geophysical study of the Western Madeira Abyssal Plain. Med. Rijks Geol. Dienst, 38-2:67-89.

Duin, E.J.T., and Kuijpers, A., 1983. Geological Studies on Abyssal Plains in the North Atlantic: Contrib. Seabed Working Group Progr. Rept. 1982, Internal Rept.: Haarlem (Rijks Geol. Dienst).

Emerson, S., Jahnke, R., Bender, M., Froelich, P., Klinkhammer, G., Bowser, B., and Setlock, G., 1980. Early diagenesis in sediments from the Eastern Equatorial Pacific. I. Pore water nutrients and carbonate results. Earth Planet. Sci. Lett., 49:57-80.

Froelich, P.N., Klinkhammer, G.P., Bender, M.L., Luedtke, N.A., Heath, G.R., Cullen, D., Dauphin, P., Hammond, D., Hartman, B., and Maynard, V., 1979. Early oxidation of organic matter in pelagic sediments of the eastern equatorial Atlantic: suboxic diagenesis. Geochim. Cosmochim. Acta, 43:1075-1090.

Gieskes, J.M., 1983. The chemistry of interstitial waters of deep-sea sediments: interpretation of deep-sea drilling data. In Riley, J.P., and Chester, R. (Eds.), Chemical Oceanography (Vol. 8): London (Academic), 221269.

Hurd, D.C., 1973. Interactions of biogenic opal, sediment and seawater in the central equatorial Pacific. Geochim. Cosmochim. Acta, 37:2257-2282.

Jarvis, I., and Higgs, N., 1987. Trace-element mobility during early diagenesis in distal turbidites: late Quaternary of the Madeira Abyssal Plain, N Atlantic. In Weaver, P.P.E., and Thomson J. (Eds.), Geology and Geochemistry of Abyssal Plains. Geol. Soc. Spec. Publ. London, 31:179214.

Keil, R.G., Hu, F.S., Tsamakis, E.C., and Hedges, J.I., 1994a. Pollen in marine sediments as an indicator of oxidation of organic matter. Nature, 369:639-641.

Keil, R.G., Montluçon, D.B., Prahl, F.G., and Hedges, J.I., 1994b. Sorptive preservation of labile organic matter in marine sediments. Nature, 370:549-551.

Kennedy, H.A., and Elderfield, J., 1987. Iodine diagenesis in non-pelagic deep sea sediments. Geochim. Cosmochim. Acta, 51:2505-2514.

Lebreiro, S.M., McCave, I.N., and Weaver, P.P.E., 1997. Late Quaternary emplacement of turbidites on the Horseshoe Abyssal Plain. J. Sediment. Res., 67:856-870.

Ludden, J.N., Gradstein, F.M., et al., 1990. Proc. ODP, Init. Repts., 123: College Station, TX (Ocean Drilling Program).

Masson, D.G., 1996. Catastrophic collapse of the volcanic island of Hierro $15 \mathrm{ka}$ ago and the history of landslides in the Canary Islands. Geology, 24:231-234.

Masson, D.G., Kidd, R.B., Gardner, J.V., Huggett, Q.J., and Weaver, P.P.E., 1992. Saharan Continental Rise: sediment facies distribution and sediment slides. In Poag, C.W., and de Graciansky, P.C. (Eds.), Geologic Evolution of Atlantic Continental Rises: New York (Van Nostrand Reinhold), 327-343.

Mayer, L.M., 1994. Surface area control of organic carbon accumulation in continental shelf sediments-a hypothesis. Geochim. Cosmochim. Acta, 58:1271-1284.

Milkert, D., Weaver, P.P.E., and Liu, L., 1996. Pleistocene and Pliocene turbidites from the Iberia Abyssal Plain. In Whitmarsh, R.B., Sawyer, D.S., Klaus, A., and Masson, D.G. (Eds.), Proc. ODP, Sci. Results, 149: College Station, TX (Ocean Drilling Program), 281-294.

Müller, D.W., Hodell, D.A., and Ciesielski, P.F., 1991. Late Miocene to earliest Pliocene (9.8-4.5 Ma) Paleoceanography of the subantarctic Southeast Atlantic: stable isotopic, sedimentologic, and microfossil evidence. In Ciesielski, P.F., Kristoffersen, Y., et al., Proc. ODP, Sci. Results, 114: College Station, TX (Ocean Drilling Program), 459-474. 
Müller, P.J., 1977. C/N ratios in Pacific deep sea sediments: effect of inorganic ammonium and organic nitrogen compounds sorbed by clays. Geochim. Cosmochim. Acta, 41:765-776.

Pearce, T.J., 1991. The geology, geochemistry, sedimentology and provenance of Late Quaternary turbidites, Madeira Abyssal Plain [Ph.D. thesis]. CNAA, Kingston Polytechnic.

Pearce, T.J., and Jarvis, I., 1992a. Applications of geochemical data to modeling sediment dispersal patterns in distal turbidites: Late Quaternary of the Madeira Abyssal Plain. J. Sediment. Petrol., 62:1112-1129.

, 1992b. Composition and provenance of turbidite sands: Late Quaternary, Madeira Abyssal Plain. Mar. Geol., 109:21-51.

1995. High-resolution chemostratigraphy of Quaternary distal turbidites: a case study of new methods for the analysis and correlation of barren sequences. In Dunay, R.E., and Hailwood, E.A. (Eds.), Non-biostratigraphical Methods of Dating and Correlation. Geol. Soc. Spec. Publ. London, 89:107-143.

Prahl, F.G., de Lange, G.J., Lyle, M., and Sparrow, M.A., 1989. Post-depositional stability of long-chain alkenones under contrasting redox conditions. Nature, 341:434-437.

Prahl, F.G., De Lange, G.J., Scholten, S., and Cowie, G.L., 1997. A case for postdepositional aerobic degradation of terrestrial organic matter in turbidite deposits from the Madeira Abyssal Plain. Org. Geochem., 27:141152 .

Pratt, L.M., 1984. Influence of paleoenvironmental factors on preservation of organic matter in the middle Cretaceous Greenhorn Formation, Pueblo Co. AAPG Bull., 68:1146-1159.

Rosenthal, Y., Lam, P., Boyle, E.A., and Thomson, J., 1995. Authigenic cadmium enrichments in suboxic sediments: precipitation and postdepositional mobility. Earth Planet. Sci. Lett., 132:99-111.

Rothwell, R.G., Pearce, T.J., and Weaver, P.P.E., 1992. Late Quaternary evolution of the Madeira Abyssal Plain, Canary Basin, NE Atlantic. Basin Res., 4:103-131.

Schmincke, H.-U., Weaver, P.P.E., Firth, J.V., et al., 1995. Proc. ODP, Init. Repts., 157: College Station, TX (Ocean Drilling Program).

Searle, R.C., 1987. Regional setting and geophysical characterization of the Great Meteor East area in the Madeira Abyssal Plain. In Weaver, P.P.E., and Thomson, J. (Eds.), Geology and Geochemistry of Abyssal Plains. Geol. Soc. Spec. London, 31:49-70.

Thomson, J., Colley, S., Higgs, N.C., Hydes, D.J., Wilson T.R.S., and Sorensen, J., 1987. Geochemical oxidation fronts in NE Atlantic distal turbidites and their effects in the sedimentary record. In Weaver, P.P.E., and Thomson, J. (Eds.), Geology and Geochemistry of Abyssal Plains. Geol. Soc. Spec. Publ. London, 31:167-177.

Thomson, J., Higgs, N.C., and Colley, S., 1989. A geochemical investigation of reduction haloes developed under turbidites in brown clay. Mar. Geol., $89: 325-330$. van Os, B., Visser, H.-J., Middelburg, J.J., and de Lange, G.J., 1993. Occurrence of thin, metal-rich layers in deep-sea sediments: a geochemical characterization of copper mobilization. Deep-Sea Res., 40:1713-1730.

von Rad, U., 1974. Great Meteor and Josephine Seamounts (eastern North Atlantic): composition and origin of bioclastic sands, carbonate and pyroclastic rocks. "Meteor" Forschungsergeb. Reihe C, 19:1-62.

Weaver, P.P.E., 1994. Determination of turbidity current erosional characteristics from reworked coccolith assemblages, Canary Basin, North-east Atlantic. Sedimentology, 41:1025-1038.

Weaver, P.P.E., and Kuijpers, A., 1983. Climatic control of turbidite deposition on the Madeira Abyssal Plain. Nature, 306:360-363.

Weaver, P.P.E., Masson, D.G., Gunn, D.E., Kidd, R.B., Rothwell, R.G., and Maddison, D.A., 1995. Sediment mass-wasting in the Canary Basin. In Pickering, K.T., Hiscott, R.N., Kenyon, N.H., Ricci Luchi, F., and Smith, R.D.A. (Eds.), Atlas of Deep Water Environments: Architectural Style in Turbidite Systems: London (Chapman and Hall), 287-296.

Weaver, P.P.E., and Rothwell, R.G., 1987. Sedimentation on the Madeira Abyssal Plain over the last 300,000 years. In Weaver, P.P.E., and Thomson, J. (Eds.), Geology and Geochemistry of Abyssal Plains. Geol. Soc. Spec. Publ. London, 31:71-86.

Weaver, P.P.E., Rothwell, R.G., Ebbing, J., Gunn, D., and Hunter, P.M., 1992. Correlation, frequency of emplacement and source directions of megaturbidites on the Madeira Abyssal Plain. Mar. Geol., 109:1-20.

Weaver, P.P.E., Searle, R.C., and Kuijpers, A., 1986. Turbidite deposition and the origin of the Madeira Abyssal Plain. In Summerhayes, C.P., and Shackleton, N.J. (Eds.), North Atlantic Palaeoceanography. Spec. Publ. Geol. Soc. London, 21:131-143.

Weaver, P.P.E., Thomson, J., and Jarvis, I. 1989. The geology and geochemistry of Madeira Abyssal Plain sediments: a review. In Freeman, T.J. (Ed.), Advances in Underwater Technology, Ocean Science and Offshore Engineering (Vol. 18): London (Graham and Trotman), 51-78.

Wilson, T.R.S., Thomson, J., Colley, S., Hydes, D.J., Higgs, N.C., and Sørensen, J., 1985. Early organic diagenesis: the significance of progressive subsurface oxidation fronts in pelagic sediments. Geochim. Cosmochim. Acta., 49:811-822.

Wilson, T.R.S, Thomson, J., Hydes, D.J., Colley, S., Culkin, F., and Sørensen, J., 1986. Oxidation fronts in pelagic sediments: diagenetic formation of metal-rich layers. Science, 232:972-975.

Date of initial receipt: 6 January 1997

Date of acceptance: 8 May 1997

Ms 157SR-136 